\title{
Novel (2-amino-4-arylimidazolyl)propanoic acids and pyrrolo[1,2-c]imidazoles via the domino reactions of 2-amino-4-arylimidazoles with carbonyl and methylene active compounds
}

\author{
Victoria V. Lipson ${ }^{* 1,2,3}$, Tetiana L. Pavlovska ${ }^{1,3}$, Nataliya V. Svetlichnaya ${ }^{2}$, \\ Anna A. Poryvai ${ }^{3}$, Nikolay Yu. Gorobets ${ }^{1}$, Erik V. Van der Eycken ${ }^{4,5}$, \\ Irina S. Konovalova ${ }^{1}$, Svetlana V. Shiskina ${ }^{1,3}$, Alexander V. Borisov ${ }^{6}$, \\ Vladimir I. Musatov ${ }^{1}$ and Alexander V. Mazepa ${ }^{7}$
}

\section{Full Research Paper}

Address:

${ }^{1}$ SSI "Institute for Single Crystals" of National Academy of Sciences of Ukraine, Nauky Ave. 60, Kharkiv 61074, Ukraine, ${ }^{2}$ Antidiabetic Drug Laboratory, SI "V.Ya. Danilevsky Institute for Endocrine Pathology Problems", Academy of Medical Sciences of Ukraine, 10, Alchevskih St., Kharkiv 61002, Ukraine, ${ }^{3}$ Chemistry Department, V.N. Karazin Kharkov National University, Kharkov 61022, Ukraine, ${ }^{4}$ Laboratory for Organic \& Microwave-Assisted Chemistry (LOMAC), Katholieke Universiteit Leuven, Celestijnenlaan 200F, B-3001 Leuven, Belgium, ${ }^{5}$ Peoples' Friendship University of Russia (RUDN University) 6 Miklukho-Maklaya street, Moscow, 117198, Russia, ${ }^{6}$ Enamine Ltd. 23 Chervonotkats'ka str., Kyiv 01003, Ukraine and ${ }^{7}$ A.V. Bogatsky physico-chemical institute of the National Academy of Sciences of Ukraine, 86, Lustdorfskaya doroga, 65080, Odessa, Ukraine

Email:

Victoria V. Lipson ${ }^{*}$ - lipson@ukr.net

* Corresponding author

Keywords:

2-amino-4-arylimidazole; (2-amino-4-arylimidazolyl)propanoic acid; isatin; Meldrum's acid; multicomponent reactions;

pyrrolo[1,2-c]imidazole; 3,3'-spirooxindoles

\begin{abstract}
The unexpectedly uncatalyzed reaction between 2-amino-4-arylimidazoles, aromatic aldehydes and Meldrum's acid has selectively led to the corresponding Knoevenagel-Michael adducts containing a free amino group in the imidazole fragment. The adducts derived from Meldrum's acid have been smoothly converted into 1,7-diaryl-3-amino-6,7-dihydro-5H-pyrrolo[1,2-c]imidazol-5ones and 3-(2-amino-4-aryl-1H-imidazol-5-yl)-3-arylpropanoic acids. The interaction of 2-amino-4-arylimidazoles with aromatic aldehydes or isatins and acyclic methylene active compounds has led to the formation of pyrrolo[1,2-c]imidazole-6-carbonitriles, pyrrolo[1,2-c]imidazole-6-carboxylates and spiro[indoline-3,7'-pyrrolo[1,2-c]imidazoles], which can be considered as the analogues of both 3,3 '-spirooxindole and 2 -aminoimidazole marine sponge alkaloids.
\end{abstract}

Beilstein J. Org. Chem. 2019, 15, 1032-1045. doi:10.3762/bjoc.15.101

Received: 24 February 2019

Accepted: 18 April 2019

Published: 06 May 2019

This article is part of the thematic issue "Multicomponent reactions III".

Guest Editor: T. J. J. Mülle

(C) 2019 Lipson et al.; licensee Beilstein-Institut.

License and terms: see end of document. 


\section{Introduction}

Heterocyclic compounds of both natural and synthetic origin, containing in their structure pyrrole and imidazole rings, display a wide set of pharmacologically significant activities. The most important natural sources of such systems are marine sponges. Since the 70 's of 20 th century up to date more than 150 derivatives containing pyrrole and 2-aminoimidazole fragments in their structure were found among the metabolites of these marine organisms [1]. This group of compounds is characterized by an exceptional molecular diversity. The main structural types of these substances are shown in Figure 1. The metabolites of Leucetta Sp. and Clathrina Sp. are presented by achiral imidazole alkaloids from the group of benzyl substituted 2-aminoimidazole (dorimidazole A (I), naamine A (II)), fused cyclic systems (2-amino-2-deoxykealiiquinone (III)) and spirolinked compounds ((-)-spirocalcaridine B (IV)) [2]. Agelas Sp. are a source of alkaloids with core structures containing simultaneously pyrrole carboxamide and 2-aminoimidazole moieties such as the simple achiral compound oroidine (V) and spatially organized molecules in a complex manner with a large number of chiral centres like (-)-palau'amine (VI) [3]. Oroidine (V) and other related vinyl 2-aminoimidazoles of this class are monomeric precursors of nagelamide A (VII), mauritiamine (VIII), sceptrin (IX), benzosceptrin A (X), axinellamines (XI) and stylissazole A (XII) alkaloids [1,4,5]. Fused 2-aminoimidazole and azepinone derivatives XIII were isolated recently from an extract of Pseudoceratina Sp. [6].<smiles>Cn1cc(Cc2ccc(O)cc2)nc1N</smiles>

I<smiles>Nc1nc(/C=C/CNC(=O)c2cc(Br)c(Br)[nH]2)c[nH]1</smiles><smiles>NC1=NC(=O)C(C2(/C=C/CNC(=O)c3cc(Br)c(Br)[nH]3)NC(N)=NC2=O)=N1</smiles>

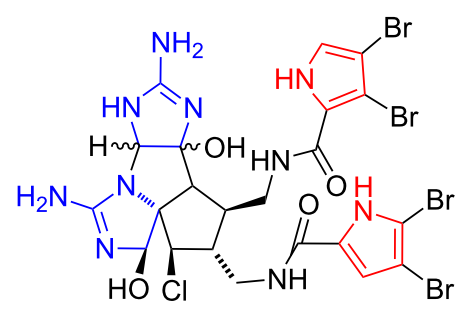

$\mathbf{X I}$<smiles>COc1ccc(Cc2nc(N)n(C)c2Cc2ccc(O)cc2)cc1</smiles><smiles>COC1=C(OC)C(=O)c2c(cc3c(nc(N)n3C)c2-c2ccccc2)C1=O</smiles>

III<smiles>COc1ccc(C2C3(C=CC(=O)C=C3)CC3(O)N(C)C(N)=NC23O)cc1</smiles>

IV<smiles>Nc1ncc(C(CCNC(=O)c2c[nH]c(Br)c2Br)c2[nH]c(N)nc2/C=C/CNC(=O)c2cc(Br)c(Br)[nH]2)[nH]1</smiles>

VI<smiles>[X][M]1cc(Br)cn1C(=O)NC1[C@@H](NC(=O)c2cc(Br)c[nH]2)[C@H](c2c[nH]c(N)n2)[C@H]1c1c[nH]c(N)n1</smiles><smiles>Nc1nc2c3c(c4nc(N)[nH]c4c2[nH]1)[C@H](NC(=O)c1ccc[nH]1)C3NC(=O)c1ccc[nH]1</smiles>

$\mathbf{X}$<smiles>[X][M]OC(=O)c1cc(Br)c[nH]1</smiles><smiles></smiles>

XIII 
The variety of types of pharmacological activity revealed in these marine sponges' metabolites is not inferior to the chemodiversity of their structure. Many of them are reported to have properties such as $\alpha$-adrenoreceptors [7] and leukotriene B4 receptor antagonists [8], cyclin-dependent kinases GSK-3 $\beta$, CK1 [9] and nitric oxide synthase activity inhibitors [10,11], as well as antibacterial [2], antifungal [12], antihistamine [13] and antitumor activities [14]. Remarkable immunosuppressive properties are inherent to palau'amine (VI) [15]. Ceratamines XIII are the disruptors of microtubule dynamics, therefore are of great interest in cancer drug discovery [6]. Thereby, the stereocontrolled total synthesis of marine alkaloids such as axinellamines [16] and the search of new 2-aminoimidazole and pyrrole containing compounds with a core structure that mimics metabolites of marine sponges with interesting biological properties has received considerable attention from both chemists and pharmacologists.

In the middle of $2000 \mathrm{~s}$, the authors of the studies [17-19] proposed a facile one-pot two-step procedure for the synthesis of diversely substituted 2 -aminoimidazoles from $\alpha$-bromocarbonyl compounds and substituted 2-aminopyrimidines. This methodology allowed the rapid synthesis of alkaloids of the isonaamine series [20] and other polysubstituted 2-aminoimidazoles with moderate cytostatic activity [21] and biofilm inhibitory activity against $S$. Typhimurium and $P$. Aeruginosa $[22,23]$.

We have used 4-aryl-substituted 2-aminoimidazoles described by the authors of the aforementioned works as polyfunctional building blocks for the formation of different fused and spirolinked heterocyclic systems. Last ones are able to act as precursors in the synthesis of the substances that mimic the core structure of marine alkaloids due to the presence of several reaction centres, which allow their further chemical modification. In the present work we disclose our results on the multicomponent reactions between 2-amino-4-arylimidazoles, aromatic aldehydes or isatins and cyclic or acyclic $\mathrm{CH}$ acids. As the last compounds we have used Meldrum's acid, malononitrile and ethyl 2-cyanoacetate.

\section{Results and Discussion}

In view of the structure of 2-amino-4-arylimidazoles containing four nonequivalent nucleophilic centres several pathways can be assumed for their reactions with carbonyl 1,3-bielectrophiles or their synthetic precursors in the case of three-component reactions between these amines, carbonyl compounds and $\mathrm{CH}$ acids. Previously, an unusual direction of the three-component reaction between 2-aminoimidazoles, aldehydes and 5,5dimethyl-1,3-cyclohexanedione has led to the formation of the Knoevenagel-Michael adducts (Figure 2) [24]. By analogy with our results obtained with the use of other aminoazoles in the reactions with benzaldehydes and Meldrum's acid [25] we expected the formation of one or several isomers of tetrahydroimidazopyrimidinone derivatives (Figure 2).

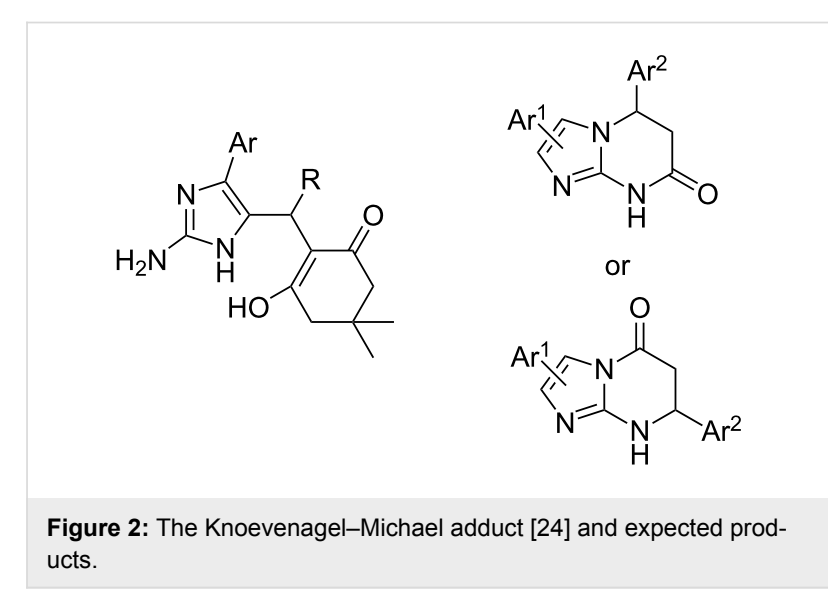

However, a short time (3-5 min) and reflux of the equimolar amounts of amines 1, para-substituted benzaldehydes $\mathbf{2}$, and Meldrum's acid $\mathbf{3}$ in 2-propanol led to Knoevenagel-Michael adducts $\mathbf{4 a - h}$ (Table 1).

Beside the short reaction times and mild conditions, this catalyst-free three-component condensation is characterized by a very facile performance since the solid products are formed as precipitates and are simply isolated in good yields without any additional purification (Table 1). In our synthetic practice this is the first example of the existence of stable $\beta$-adducts, which simultaneously contain Meldrum's acid and aminoazole fragments. In all earlier described experiments with participation of different $\alpha$-aminoazoles as binucleophiles the reaction cascade readily accomplished by the formation of fused heterocyclic systems [25].

An analogous three-component reaction involving indole or imidazo[1,2-a]pyridine derivatives instead of 2-aminoimidazoles is referred in the literature as Yonemitsu reaction or Yonemitsu-like reaction [26-31]. The similar Michael-type adducts 6 were isolated [31] from the reaction of imidazo[1,2-a]pyridine with aldehydes and Meldrum's acid in acetonitrile in the presence of a catalytic amount of proline (Scheme 1) and then they were successfully converted to the appropriate esters 7 and acids $\mathbf{8}$.

In our case, we have isolated products $\mathbf{4 a}-\mathbf{h}$ individually and characterized them by IR, ${ }^{1} \mathrm{H},{ }^{13} \mathrm{C} \mathrm{NMR}$, and mass-spectral methods. The ${ }^{1} \mathrm{H}$ NMR spectra of products 4 have two characteristic broad singlets that represent the exchangeable proton shifts of the crossed signals of $\mathrm{NH}$ and $\mathrm{OH}$ groups at 
Table 1: Three-component condensation of 2-amino-4-arylimidazoles, aldehydes and Meldrum's acid.

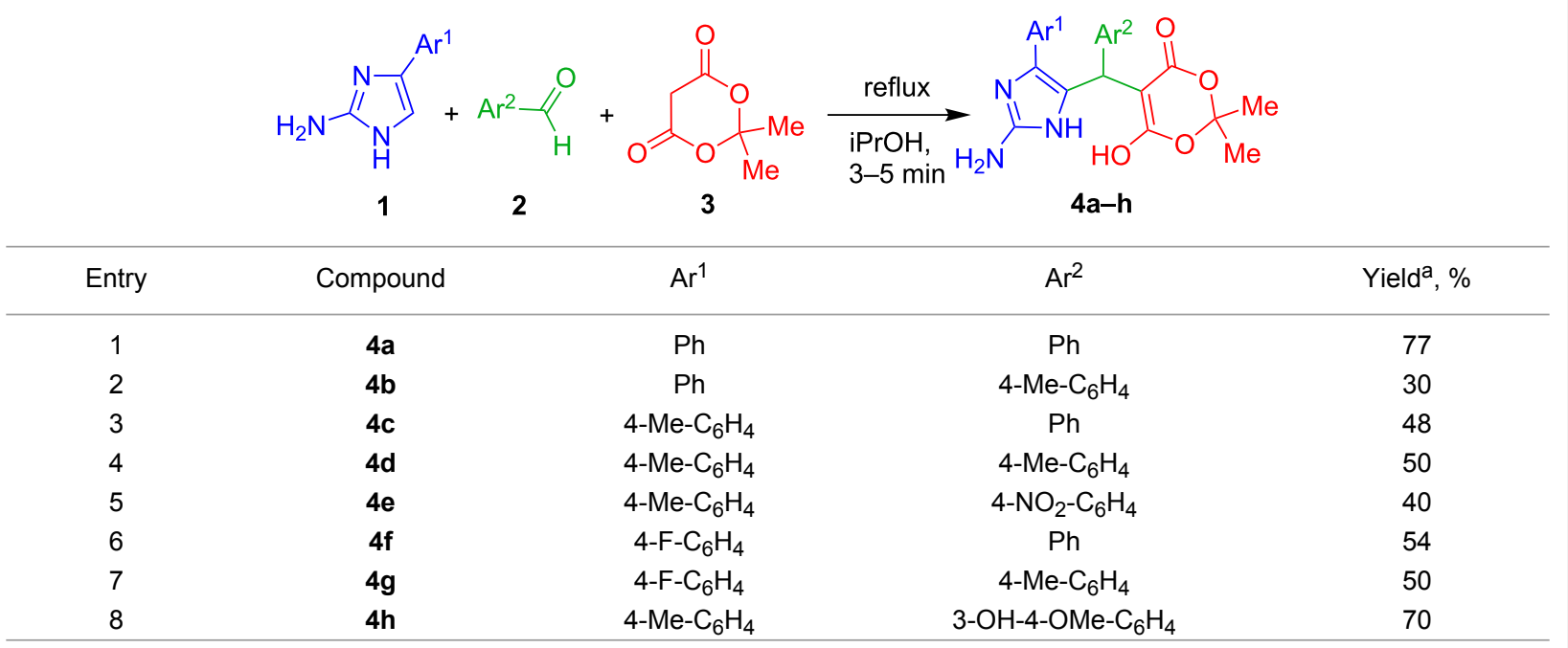

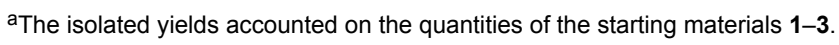

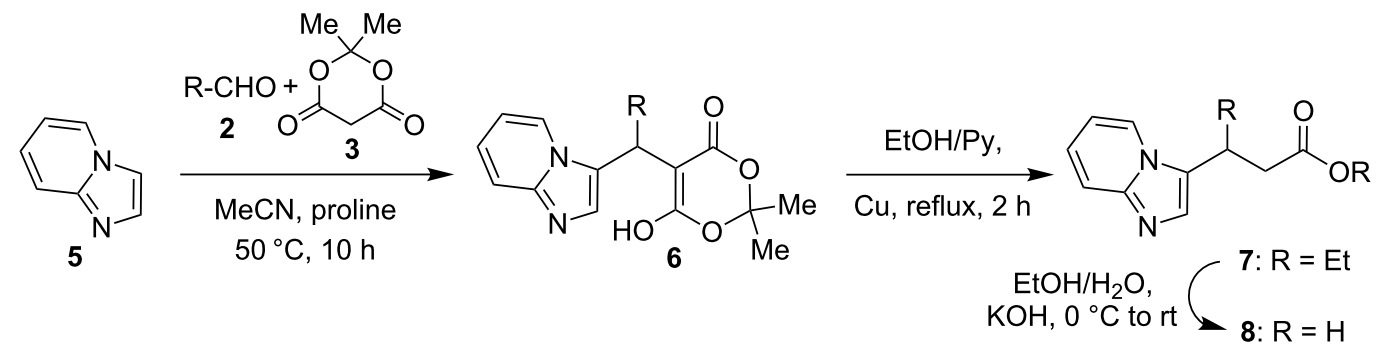

Scheme 1: The three component condensation of imidazo[1,2-a]pyridine, aldehydes and Meldrum's acid described by Gerencsér at al. [31].

12.35-11.61 ppm and the $\mathrm{NH}_{2}$ group of the aminoimidazole fragment at 7.47-7.26 ppm, as well as a singlet for the protons of two methyl groups. The existence of the dioxanedione cycle in enol form is proven by the presence of the singlet of a methyne proton near the saturated carbon atom at 5.42-5.56 ppm and the absence of the signal for the methyne proton of the dioxanedione cycle. With regard to the mass spectra, all compounds $\mathbf{4}$ exhibit similar behaviour in their fragmentation, showing the absence of the molecular ion peak and the presence of intense signals that occur due to cleavage of acetone and $\mathrm{CO}_{2}$ molecules from the dioxanedione moieties.

Their further transformation took place in the presence of the catalytic amounts of TFA in toluene under short time reflux ( $3 \mathrm{~min}$ ) or addition of the catalytic amounts of TFA to the initial three-component mixture (Table 2).

The reaction proceeded via 1,3-dioxanedione cycle cleavage followed by elimination of acetone and $\mathrm{CO}_{2}$ to provide novel pyrrolo[1,2-c]imadazol-5-ones trifluoroacetates $\mathbf{9 b , c , i}$ precipitated from the reaction mixture (Table 2). The corresponding bicyclic amine 10a was obtained by the prolonged treatment of the product 4a with catalytic amounts of TFA in acetonitrile followed by the addition of an aqueous solution of $\mathrm{NH}_{3}$.

The structures of cyclized products $\mathbf{9}$ and $\mathbf{1 0}$ were confirmed by spectral methods. The signals of $\mathrm{NH}, \mathrm{OH}$ and methyl groups of the dioxanedione cycle are absent in the ${ }^{1} \mathrm{H}$ NMR spectra of trifluoroacetates 9 . The broad signal of the $\mathrm{NH}_{2}$ group shifts to the downfield signal of $\mathrm{NH}_{3}{ }^{+}$at $8.5-8.2 \mathrm{ppm}$. Protons of the $\mathrm{CH}_{2}-\mathrm{CH}$ fragment in the pyrrolidine cycle show the shifts of an $\mathrm{ABX}$ system for $\mathrm{CH}_{\mathrm{X}}$ at $4.73-4.85, \mathrm{CH}_{\mathrm{B}}$ at $3.81-3.84, \mathrm{CH}_{\mathrm{A}}$ at $2.86-2.95 \mathrm{ppm}$. The same situation is observed for compound 10a, however, the signal of the free $\mathrm{NH}_{2}$ group of the aminoimidazole moiety shifts to $6.36 \mathrm{ppm}$. The common feature of the mass spectra of salts 9 is the absence of the salt molecular ion peak and the presence of the intense signals that occur due to cleavage of the $\mathrm{CF}_{3} \mathrm{COO}^{-}$anion. 
Table 2: Synthesis of compounds 9b,c,i, 10a, 11b-g.<smiles>CC1(C)OC(=O)C(C([Al])c2[nH]c(N)nc2Br)=C(O)O1</smiles>

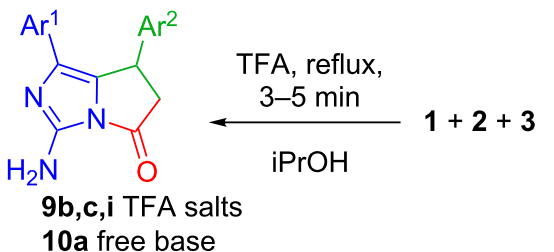

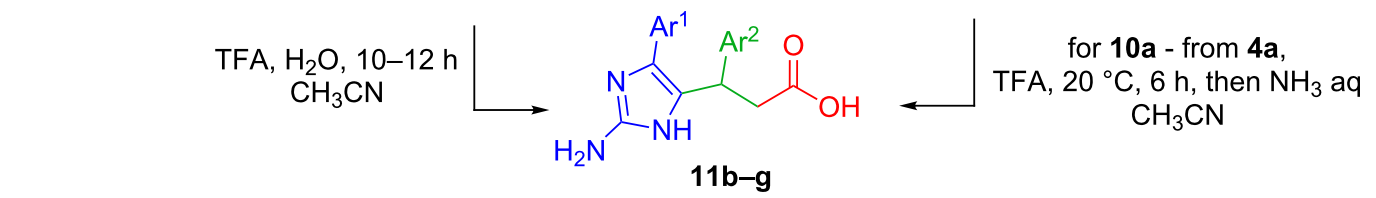

\begin{tabular}{|c|c|c|c|c|}
\hline Entry & Compound & $\mathrm{Ar}^{1}$ & $\mathrm{Ar}^{2}$ & Yield, \% \\
\hline 1 & $9 b$ & $\mathrm{Ph}$ & $4-\mathrm{Me}-\mathrm{C}_{6} \mathrm{H}_{4}$ & 52 \\
\hline 2 & $9 c$ & $4-\mathrm{Me}-\mathrm{C}_{6} \mathrm{H}_{4}$ & $\mathrm{Ph}$ & 60 \\
\hline 3 & $9 \mathbf{i}$ & $4-\mathrm{Ph}-\mathrm{C}_{6} \mathrm{H}_{4}$ & $\mathrm{Ph}$ & 71 \\
\hline 4 & $10 a$ & $\mathrm{Ph}$ & $\mathrm{Ph}$ & 68 \\
\hline 5 & $11 b$ & $\mathrm{Ph}$ & 4-Me- $\mathrm{C}_{6} \mathrm{H}_{4}$ & 55 \\
\hline 6 & $11 c$ & 4-Me- $\mathrm{C}_{6} \mathrm{H}_{4}$ & $\mathrm{Ph}$ & 76 \\
\hline 7 & $11 d$ & $4-\mathrm{Me}-\mathrm{C}_{6} \mathrm{H}_{4}$ & $4-\mathrm{Me}-\mathrm{C}_{6} \mathrm{H}_{4}$ & 65 \\
\hline 8 & $11 \mathrm{e}$ & 4-Me- $\mathrm{C}_{6} \mathrm{H}_{4}$ & $4-\mathrm{NO}_{2}-\mathrm{C}_{6} \mathrm{H}_{4}$ & 60 \\
\hline 9 & $11 f$ & $4-\mathrm{F}-\mathrm{C}_{6} \mathrm{H}_{4}$ & $\mathrm{Ph}$ & 67 \\
\hline 10 & $11 \mathrm{~g}$ & $4-\mathrm{F}-\mathrm{C}_{6} \mathrm{H}_{4}$ & $4-\mathrm{Me}-\mathrm{C}_{6} \mathrm{H}_{4}$ & 85 \\
\hline
\end{tabular}

Single crystal X-ray diffraction analysis of biphenyl compound 9i has finally proved the structures of the obtained products (Figure 3).
Compound 9i exists as organic salt with trifluoroacetic acid in the crystal phase. The existence of the trifluoroacetic molecule as anion is confirmed by close values of the $\mathrm{C}-\mathrm{O}$ bond lengths
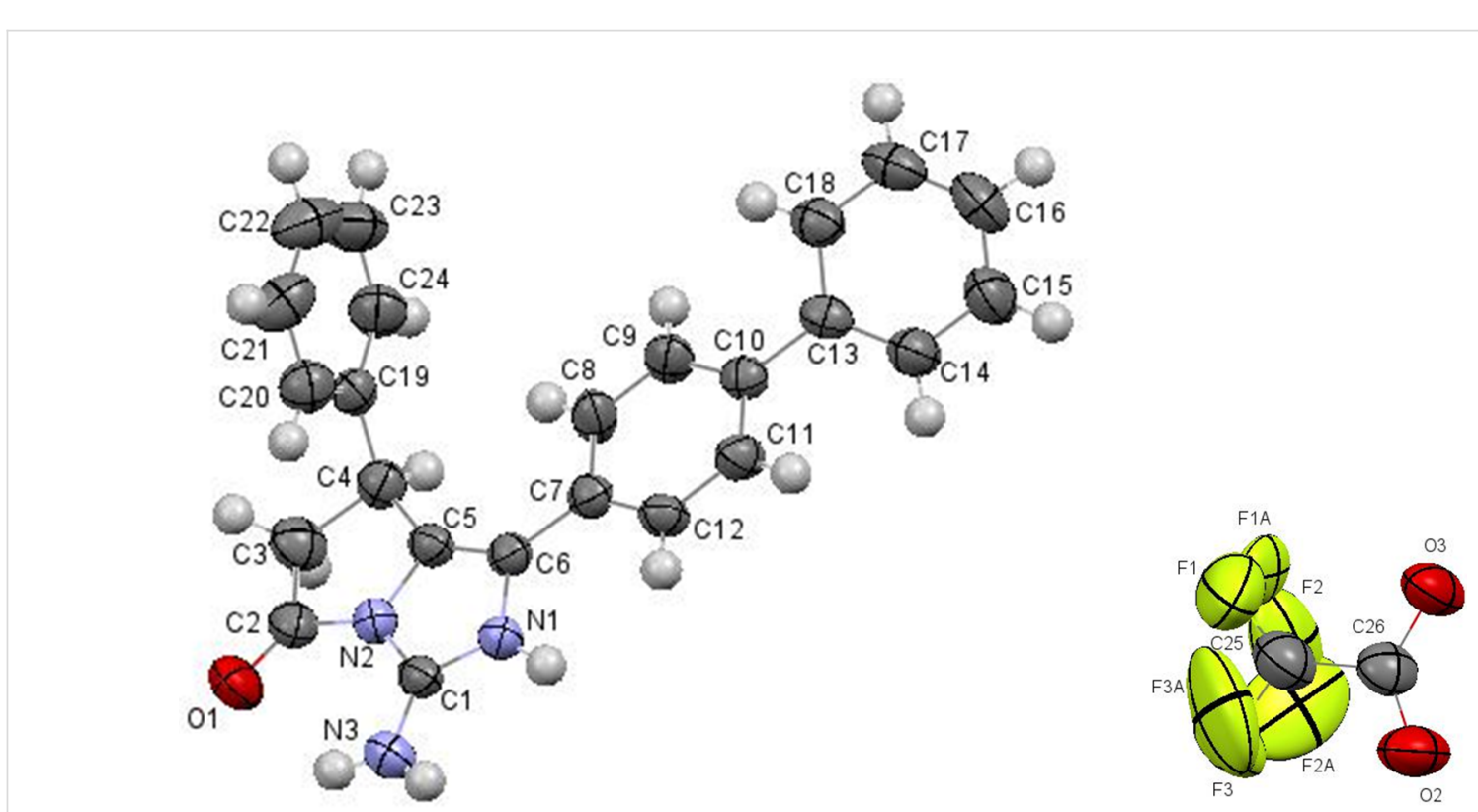

Figure 3: Molecular structure of 1-([1,1'-biphenyl]-4-yl)-5-oxo-7-phenyl-6,7-dihydro-5H-pyrrolo[1,2-c]imidazol-3-aminium 2,2,2-trifluoroacetate 9i according to X-ray diffraction data. Thermal ellipsoids of atoms are shown at $50 \%$ probability level. 
(1.229(2) $\AA$ and 1.238(2) $\AA$, respectively) and the absence of the hydrogen atom at the carboxylic group. The analysis of the bond lengths in the imidazole ring has revealed that the $\mathrm{C} 1-\mathrm{N} 1$ and $\mathrm{C} 1-\mathrm{N} 3$ bonds are equal (1.320(3) $\AA$ and 1.320(2) $\AA$, respectively) and the N1-C6 bond (1.414(6) $\AA$ ) is slightly elongated as compare to its mean value $1.376 \AA$ [32]. The hydrogen atoms at the $\mathrm{N} 1$ and $\mathrm{N} 3$ were located from the electron density difference maps. As a result we may describe the structure of the organic cation as superposition of two forms (Scheme 2).<smiles>Nc1[nH+]c([AlH2])c2n1C(=O)CC2[Al]</smiles>

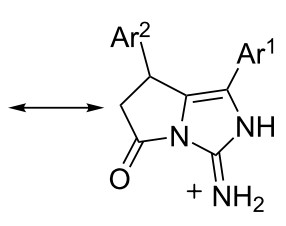

Scheme 2: Two forms of cation 9 i.

The prolonged reflux $(10 \mathrm{~h}$ ) of compounds $\mathbf{4 b}-\mathbf{g}$ in acetonitrile in the presence of a catalytic amount of TFA leads to the opening of the pyrrolidone ring followed by the formation of acids $\mathbf{1 1 b}-\mathbf{g}$ (Table 2). The process remarkably accelerates while adding water to the reaction mixture. The acids $\mathbf{1 1}$ can also be obtained from pyrrolo[1,2-c]imidazol-3-aminium trifluoroacetates 9 after prolonged reflux (12 h) in aqueous acetonitrile.

The ${ }^{1} \mathrm{H}$ NMR spectra of acids $\mathbf{1 1}$ contain the signals of the protons of the aromatic system, the broad singlet for $\mathrm{NH}_{2}$ group at 5.87-5.82 ppm and the signals of the $\mathrm{ABX}$ protons of the propionyl fragment $-\mathrm{CH}_{\mathrm{X}}$ at $4.60-4.30 \mathrm{ppm}$ and $\mathrm{CH} 2 \mathrm{AB}$ at $3.00-2.60 \mathrm{ppm}$.

Finally, the structure of acids $\mathbf{1 1}$ was confirmed by X-ray diffraction data of the sample compound 11b (Figure 4).

Compound 11b was found to be a zwitterion and exists as monohydrate in the crystal phase. The absence of the hydrogen atom and equalization of the $\mathrm{C} 6-\mathrm{O} 1$ and $\mathrm{C} 6-\mathrm{O} 2$ bond lengths (1.254(2) $\AA$ and 1.259(2) $\AA$, respectively) allow presuming the location of the negative charge at the deprotonated carboxylic group. The very close lengths of the bonds centred at the $\mathrm{C} 1$ atom (the N2-C1 bond length is 1.332(2) $\AA$, the $\mathrm{C} 1-\mathrm{N} 3$ bond length is $1.337(3) \AA$ and the N1-C1 bond length is $1.340(2) \AA$ ) allows to describe the zwitterion as superposition of three forms with different location of the positive charge (Scheme 3).

Literatur data concerning pyrrolo[1,2-c]imidazol-5-ones is quite limited and the known 6,7-dihydro analogs are represented only by several substances $[33,34]$. Partially hydrogenated pyrrolo[1,2-c]imidazole is a part of $( \pm)$-axinellamines $\mathbf{1 1}$.

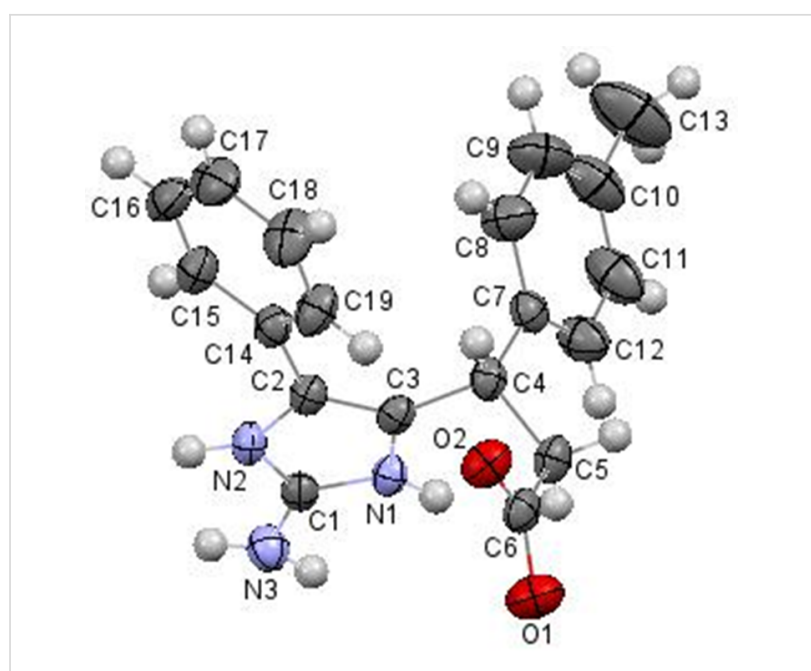

Figure 4: Molecular structure of 3-(2-amino-4-phenyl-1H-imidazol-5yl)-3-(p-tolyl)propanoic acid $11 \mathrm{~b}$ according to X-ray diffraction data. Thermal ellipsoids of atoms are shown at $50 \%$ probability level.

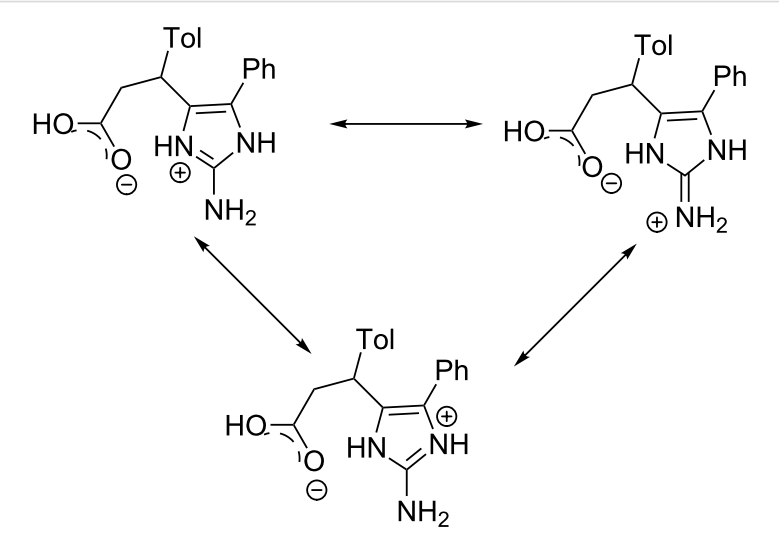

Scheme 3: Three forms of the compound $11 \mathrm{~b}$ in the crystal phase.

4-[(5R)-6,7-Dihydro-5H-pyrrolo[1,2-c]imidazol-5-yl]-3-fluorobenzonitrile (LCI-699, osilodrostat) is considered as an inhibitor of aldosterone synthase (CYP11B2) and 11 $\beta$-hydroxylase (CYP11B1), which is responsible for cortisol production [35]. This compound is under development for the treatment of Cushing's syndrome and pituitary ACTH hypersecretion [36]. From this point of view the approach to pyrrolo[1,2-c]imidazole moiety by using acyclic methylene active compounds, that can lead to cyclic products, has a high potential for diversityoriented synthesis.

In the three-component condensations of equimolar amounts of 2-amino-4-arylimidazoles 1, para-substituted benzaldehydes 2 and malononitrile (12) in 2-propanol the Knoevenagel-Michael adduct was not obtained. The reaction was complete to form a mixture of pyrrolo[1,2-c]imidazol-6-carbonitriles 13 and their azomethine derivatives 14 (Scheme 4). 


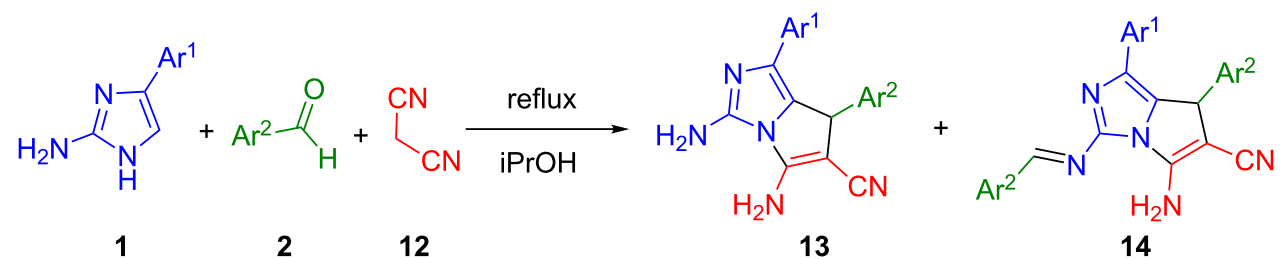

Scheme 4: Synthesis of the mixture of compounds 13 and 14.

The use of a double excess of aromatic aldehydes $\mathbf{2}$ in this condensation prevented the formation of a mixture of substances and led to the formation of individual 5-amino-3-(arylidenamino)-1-aryl-7-aryl-7H-pyrrolo[1,2-c]imidazole-6-carbonitriles $\mathbf{1 4}$, as well as azomethines $\mathbf{1 6}$ in case of using ethyl 2-cyanoacetate $\mathbf{1 5}$ as the acyclic methylene active compound (Table 3).

The isolated products $\mathbf{1 4 a - f}$ and $\mathbf{1 6 a}, \mathbf{b}$ were characterized by IR, ${ }^{1} \mathrm{H},{ }^{13} \mathrm{C}$ NMR and mass-spectral methods. The mass spectra of compounds $\mathbf{1 4}$ and $\mathbf{1 6}$ show the similar type of fragmentation. They contain peaks of molecular ions, as well as signals corresponding to the loss of fragments $\left[\mathrm{M}^{+\bullet}-\mathrm{NH}_{2},-\mathrm{CN}\right]$, $\left[\mathrm{M}^{+\bullet}-\operatorname{ArCHN}\right],\left[\mathrm{M}^{+\bullet}-\mathrm{NH}_{2},-\mathrm{CN},-\mathrm{CAr}\right]$. From the comparison of these data with the results of elemental analysis, it follows that in the formation of condensed systems $\mathbf{1 4}$ with the participation of two molecules of aromatic aldehydes two molecules of water were cleaved. In the IR spectra, the most characteristic bands represent the absorption of $\mathrm{NH}_{2}$ groups at 3420 and $3332 \mathrm{~cm}^{-1}$ and the nitryl group $\mathrm{CN}$ at $2250 \mathrm{~cm}^{-1}$. In addition, there are characteristic bands at $1664-1668 \mathrm{~cm}^{-1}$, which may include both $\mathrm{C}=\mathrm{C}$ bond and the exocyclic $\mathrm{C}=\mathrm{N}$ bond. Fluctuations of endocyclic $\mathrm{C}=\mathrm{N}$ fragments are observed at $1584 \mathrm{~cm}^{-1}$. Thus, at least one nitrile and one $\mathrm{NH}_{2}$ group are present in the obtained compounds. The ${ }^{1} \mathrm{H}$ NMR spectra of compounds 14 along with protons of aryl substituents contain the characteristic singlet of the azomethine fragment at 9.24-9.34 ppm and a singlet of the methyne protone $\mathrm{C}^{7} \mathrm{H}$ at 5.26-5.36 ppm. Formation of the azomethine fragment during the interaction of the second molecule of the aromatic aldehyde with the $\mathrm{C}^{2}-\mathrm{NH}_{2}$ group of the imidazole moiety is confirmed by the disappearance of the singlet at 5.17-5.26 ppm, which is inherent to the $\mathrm{NH}_{2}$ group at the $\mathrm{C}^{2}$ position of the imidazole ring. Instead, in the spectra, a broad singlet of the $\mathrm{C}^{5}-\mathrm{NH}_{2}$ group of the imidazo[1,2-c]pyrrole cycle appears at 7.55-7.63 ppm. The absence in ${ }^{1} \mathrm{H}$ NMR spectra of the signal of the $\mathrm{CH}$ of proton of the imidazole cycle at $6.97-7.10 \mathrm{ppm}$ shows that the reaction takes place in the $\mathrm{C}^{5}$ nucleophilic centre of the aminoazole. The ${ }^{1} \mathrm{H}$ NMR spectra of compounds $\mathbf{1 6}$ show the resonance of the ethyl group of the ethyl 2-cyanoacetate substituent as a triplet of a $\mathrm{CH}_{3}$ group at $1.02 \mathrm{ppm}, J=7.02 \mathrm{~Hz}$ and multiplets of the $\mathrm{CH}_{2}$ group at 3.85-4.03 ppm. The

Table 3: Synthesis of compounds 14 and 16.

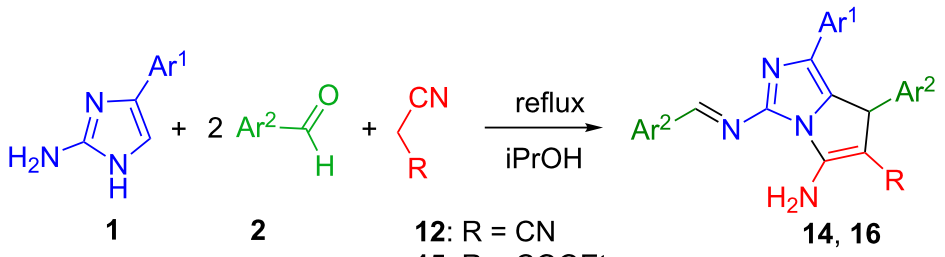

15: $R=$ COOEt

\begin{tabular}{|c|c|c|c|c|}
\hline Entry & Compound & $\operatorname{Ar}^{1}$ & $A r^{2}$ & Yield, \% \\
\hline 1 & $14 a$ & $\mathrm{Ph}$ & $4-\mathrm{Me}-\mathrm{C}_{6} \mathrm{H}_{4}$ & 65 \\
\hline 2 & $14 b$ & $4-\mathrm{Cl}-\mathrm{C}_{6} \mathrm{H}_{4}$ & $\mathrm{Ph}$ & 83 \\
\hline 3 & $14 c$ & $4-\mathrm{OMe}-\mathrm{C}_{6} \mathrm{H}_{4}$ & $\mathrm{Ph}$ & 45 \\
\hline 4 & $14 d$ & $\mathrm{Ph}$ & $4-\mathrm{Br}-\mathrm{C}_{6} \mathrm{H}_{4}$ & 40 \\
\hline 5 & $14 e$ & $\mathrm{Ph}$ & $4-\mathrm{F}-\mathrm{C}_{6} \mathrm{H}_{4}$ & 58 \\
\hline 7 & $14 f$ & 4-Me- $\mathrm{C}_{6} \mathrm{H}_{4}$ & $4-\mathrm{Br}-\mathrm{C}_{6} \mathrm{H}_{4}$ & 59 \\
\hline 8 & $16 a$ & $\mathrm{Ph}$ & $\mathrm{Ph}$ & 30 \\
\hline 9 & $16 b$ & $\mathrm{Ph}$ & $4-\mathrm{Br}-\mathrm{C}_{6} \mathrm{H}_{4}$ & 40 \\
\hline
\end{tabular}


${ }^{1} \mathrm{H}$ NMR spectra of derivatives $\mathbf{1 6}$ are similar with the spectra of compounds 14 by the absence of the resonance of the $\mathrm{NH}_{2}$ group and methyne proton of the aminoimidazole ring, which allows to classify them as compounds of the same type containing a fused aminoimidazo[1,2-c]pyrrole moiety.

Finally, the structure of azomethines $\mathbf{1 6}$ was confirmed by $\mathrm{X}$-ray diffraction data of the sample compound 16a (Figure 5).

All atoms of the bicyclic fragment lie in the plane within $0.01 \AA$. The analysis of the bond lengths has shown that the formally single exocyclic $\mathrm{C} 1-\mathrm{N} 3$ bond is shorter than the double endocyclic C6-C1 bond (1.336(6) $\AA$ and 1.354(9) $\AA$, respectively). The $\mathrm{C} 1$ and $\mathrm{C} 6$ atoms are planar indicating their $\mathrm{sp}^{2}$ hybridization. Such a distribution of electron density allows to discuss the zwitter-ionic form and to consider the structure of 16a as superposition of two resonance structures (Scheme 5).

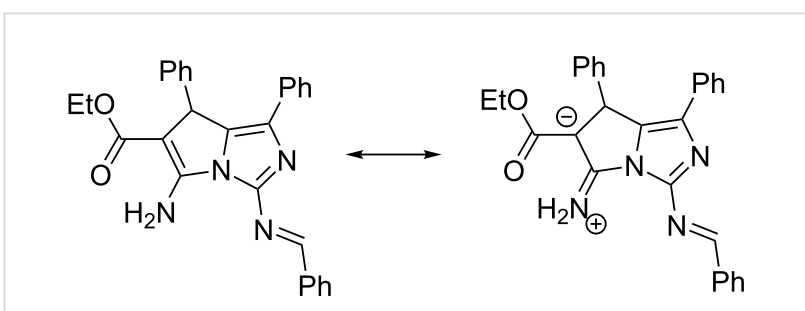

Scheme 5: Resonance structures of $16 a$.
In the next step of our research we have involved isatin $\mathbf{1 8}$ as the compound bearing a carbonyl group, as well in this case the pyrolo[1,2-c]imidazole moiety will be spiro-fused with the oxindole moiety, and the resulting structures can be considered as analogues of 3,3'-spiroxindole alkaloids, such as spirotryprostatin B (17, Figure 6) [37].<smiles>[R1]N1C(=O)[C@]2(CCNC2)c2ccccc21</smiles>

3,3'-spirooxindole core

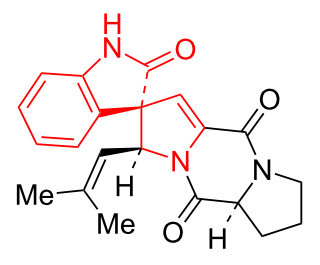

17
Figure 6: 3,3'-Spirooxindole alkaloids.

Indeed, the equimolar three-component reactions with the participation of 2-amino-4-arylimidazoles $\mathbf{1}$, isatins $\mathbf{1 8}$ and acyclic methylene active compounds $\mathbf{1 2}$ and $\mathbf{1 5}$ have completed with the formation of spirooxindoles $19 \mathbf{a}-\mathbf{h}$ and $\mathbf{2 0 a}-\mathbf{c}$, respectively, with moderate to high yields (Table 4). The reduced reactivity of the carbonyl group of isatins compared with benzaldehydes, and the greater stability of their Knoevenagel adducts leads to the formation of individual spiro compounds, not to a mixture

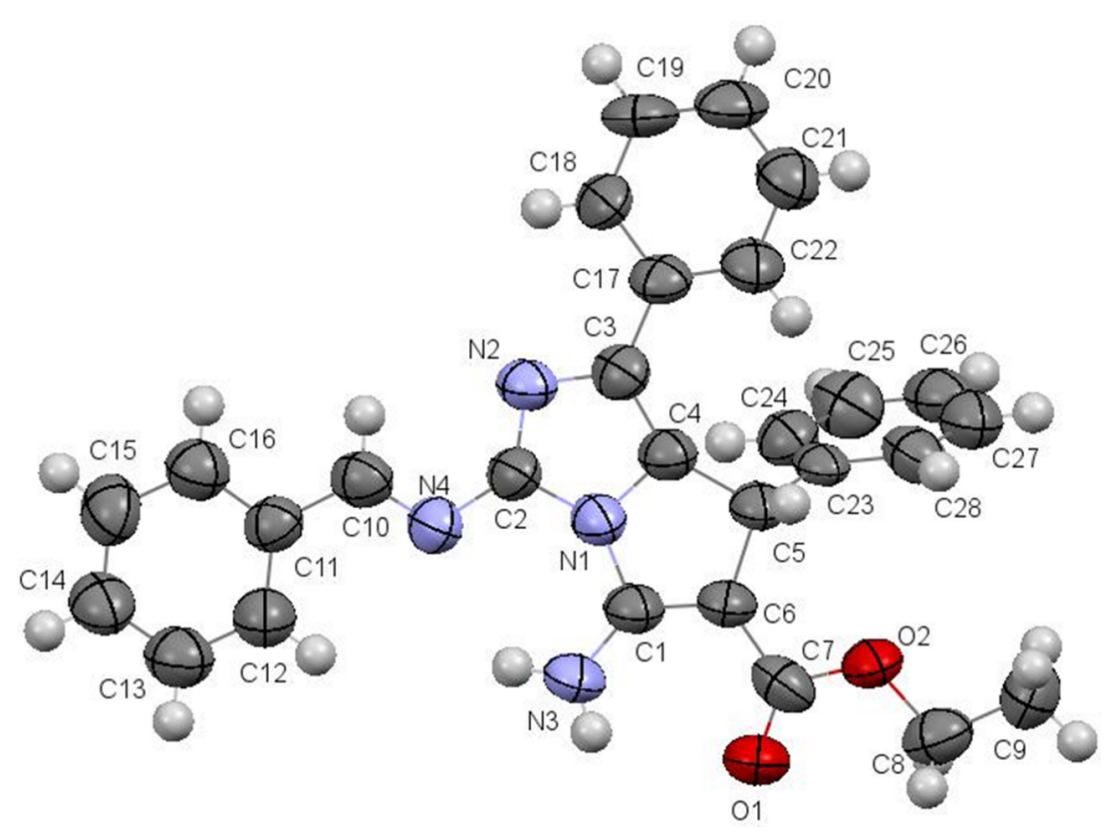

Figure 5: Molecular structure of aminoimidazo[1,2-c]pyrrole 16a according to X-ray diffraction data. Thermal ellipsoids of atoms are shown at 50\% probability level. 
Table 4: Synthesis of spirooxindoles 19 and 20.
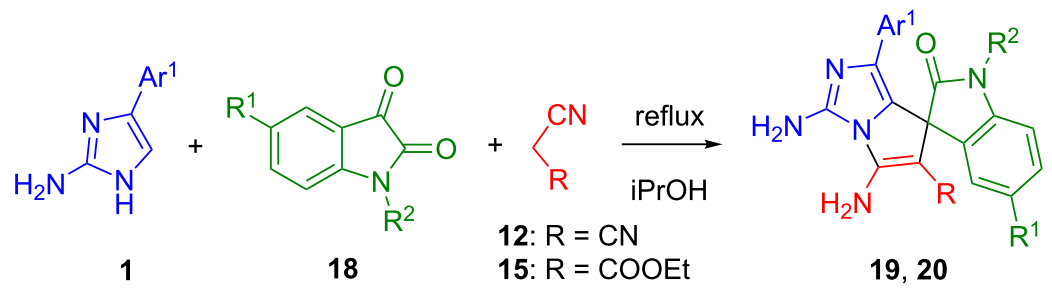

19,20

\begin{tabular}{|c|c|c|c|c|c|}
\hline Entry & Compound & $\mathrm{Ar}^{1}$ & $\mathrm{R}^{1}$ & $\mathrm{R}^{2}$ & Yield, \% \\
\hline 1 & $19 a$ & $\mathrm{Ph}$ & $\mathrm{H}$ & $\mathrm{Me}$ & 60 \\
\hline 2 & $19 b$ & $\mathrm{Ph}$ & $\mathrm{Br}$ & $\mathrm{Me}$ & 68 \\
\hline 3 & $19 c$ & $\mathrm{Ph}$ & $\mathrm{Me}$ & $\mathrm{Me}$ & 60 \\
\hline 4 & $19 d$ & $\mathrm{Ph}$ & $\mathrm{F}$ & $4-\mathrm{ClC}_{6} \mathrm{H}_{4} \mathrm{CH}_{2}$ & 40 \\
\hline 5 & $19 e$ & $4-\mathrm{Me}-\mathrm{C}_{6} \mathrm{H}_{4}$ & $\mathrm{H}$ & $\mathrm{Me}$ & 68 \\
\hline 7 & $19 f$ & 4-Me- $\mathrm{C}_{6} \mathrm{H}_{4}$ & $\mathrm{Br}$ & $\mathrm{Me}$ & 65 \\
\hline 8 & $19 \mathrm{~g}$ & $4-\mathrm{F}-\mathrm{C}_{6} \mathrm{H}_{4}$ & $\mathrm{Br}$ & $\mathrm{Me}$ & 40 \\
\hline 9 & $19 \mathrm{~h}$ & $4-\mathrm{Me}-\mathrm{C}_{6} \mathrm{H}_{4}$ & $\mathrm{Cl}$ & $\mathrm{Me}$ & 48 \\
\hline 10 & $20 a$ & $\mathrm{Ph}$ & $\mathrm{H}$ & $\mathrm{Me}$ & 72 \\
\hline 11 & $20 b$ & $4-\mathrm{OMe}-\mathrm{C}_{6} \mathrm{H}_{4}$ & $\mathrm{Br}$ & $\mathrm{Me}$ & 43 \\
\hline 12 & $20 c$ & $4-\mathrm{Me}-\mathrm{C}_{6} \mathrm{H}_{4}$ & $\mathrm{Br}$ & $\mathrm{Me}$ & 60 \\
\hline
\end{tabular}

of substances. However, condensations with the use of N-unsubstituted isatins are accompanied by the resinification of the reaction mixture, which may be caused by competing reactions of heterocyclization of the mentioned Knoevenagel adducts. In similar reactions described in the literature [38-40], the authors recognized the importance of protecting the amide fragment of isatin, since it affects the reactivity and, in some cases, the enantioselectivity of processes. In order to prevent undesirable side reactions in the future, three-component condensations were carried out using $\mathrm{N}$-substituted isatins.

The isolated products $19 \mathbf{a}-\mathbf{h}$ and $\mathbf{2 0 a}-\mathbf{c}$ were characterized by IR, ${ }^{1} \mathrm{H},{ }^{13} \mathrm{C}$ NMR and mass-spectral methods. The ${ }^{1} \mathrm{H}$ NMR spectra of spirooxindoles 19a-h and 20a-c, along with protons of aryl substituents of imidazole and isatin contain a broad singlet with $2 \mathrm{H}$ intensity of the $\mathrm{C}^{5}-\mathrm{NH}_{2}$ group of the imidazo[1,2-c]pyrrole cycle at 7.74-7.84 ppm. A characteristic feature is the appearance of another broad singlet at the 6.37-6.46 ppm, inherent to the amino group of the $C^{2}$ atom of the imidazole ring, whose chemical shift is affected by the character of the substituents in 2-amino-4-arylimidazoles. The multiplets of the $\mathrm{C}^{6}$-ethoxy group of the compounds $\mathbf{2 0 a}-\mathbf{c}$ are seen at $0.62-0.88\left(\mathrm{OCH}_{2} \mathrm{CH}_{3}\right)$ and 3.57-3.85 ppm $\left(\mathrm{OCH}_{2} \mathrm{CH}_{3}\right)$ The ${ }^{13} \mathrm{C}$ NMR spectra of spirooxindoles $19 \mathbf{a}-\mathbf{h}$ and $\mathbf{2 0 a}-\mathbf{c}$ are represented by the groups of singlets at the 66.86-69.83 and $152.29-154.72 \mathrm{ppm}$. The signal of the spiro atom is seen as a singlet at 53.53-56.03 ppm. Signals of the carbon atoms of the imidazole ring are located in the resonance region of the carbon atoms of the aryl substituents. Taken together, these data indicate the formation of the pyrrolo[1,2-c]imidazole cyclic system.

Finally, the structures of spiroxindoles $\mathbf{1 9}$ and $\mathbf{2 0}$ were confirmed by X-ray diffraction data of the sample compound 19a (Figure 7).

Compound 19a exists in the crystal phase as solvate with dimethylformamide and water in a 1:1:1 ratio.

The spiro-joined bicyclic fragments are turned relatively to each other in such a way that the dihedral angle between mean planes of the bicycles is $84.5^{\circ}$. The analysis of the bond lengths has shown that the formally single exocyclic C6-N6 bond is significantly shorter than the double endocyclic C6-C5 bond (1.319(2) $\AA$ and 1.373(3) $\AA$, respectively). The C1 and C6 atoms are planar indicating their $\mathrm{sp}^{2}$ hybridization. Such a distribution of electron density allows discussing the zwitter-ionic form and considering the structure of 19a as superposition of two resonance structures similar to $\mathbf{1 6 a}$ (Scheme 6).

\section{Conclusion}

In the described three-component reactions with aldehydes or isatins and cyclic or acyclic $\mathrm{CH}$ acids the $\mathrm{C}^{5}$ reaction centre in the 2-amino-4-arylimidazoles possesses higher nucleophilicity than both the exo- and endocyclic amino groups. Regarding the short reaction times of novel Yonemitsu-type reactions that has been achieved without application of any catalyst we assume 


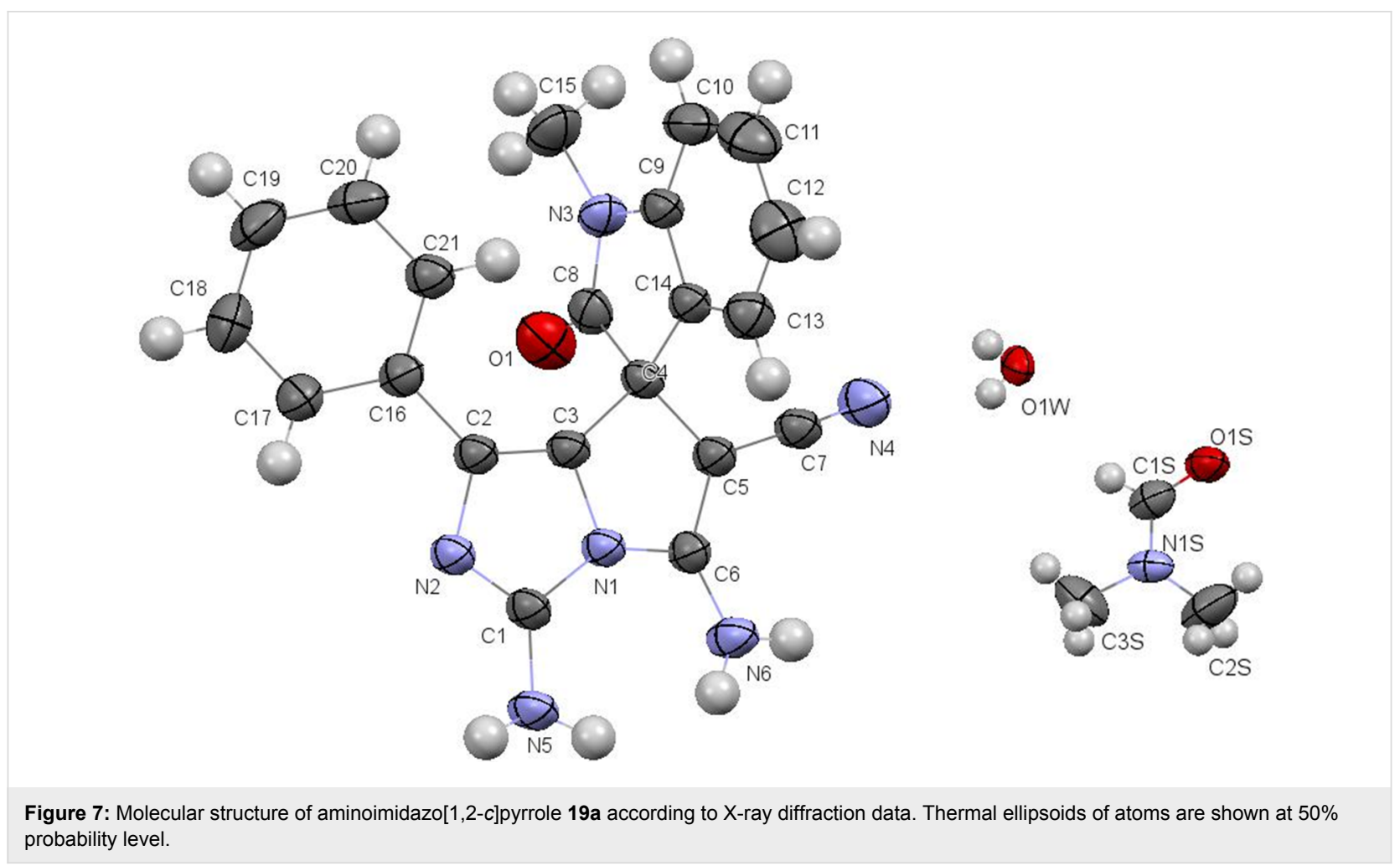<smiles>CN1C(=O)C2(C(C#N)=C(N)n3c(N)nc(-c4ccccc4)c32)c2ccccc21</smiles><smiles>CN1C(=O)C2(c3ccccc31)c1c(-c3ccccc3)nc(N)n1C(=O)C2C#N</smiles>

Scheme 6: Resonance structures of 19a.

that 2-amino-4-arylimidazoles are more reactive substrates for these syntheses leading to the stable Michael-type adducts with aldehydes and Meldrum's acid than the previously investigated indole and imidazo[1,2- $a$ ]pyridine. Moreover, as it has been shown that their further transformations may result in the formation of both unexplored heterocyclic systems containing a free amino group open for chemical modifications and the corresponding hetarylpropanoic acids providing useful templates for the synthesis of some marine alkaloids or their analogues.

In domino reactions of the 2-amino-4-arylimidazoles with isatins and aliphatic $\mathrm{CH}$ acids stable Michael adducts have not been fixed. Cyclocondensation has readily led to the formation of 6'-substituted 3',5'-diamino-1-alkyl-2-oxo-1'-arylspiro[indolin-3,7'-pyrrolo[1,2-c]imidazoles], which can be considered as the analogues of alkaloids with both pyrrolo[1,2- c]imidazol and 3,3'-spiroxindole fragments in the core structure.

\section{Experimental}

Reagents and analytics: Starting materials were purchased from commercial suppliers. Melting points were determined on a Kofler apparatus and temperatures were not corrected. The IR spectra were recorded in $\mathrm{KBr}$ on a Specord M-82 spectrometer. The ${ }^{1} \mathrm{H}$ NMR spectra were measured on a Varian Mercury VX-200 (200 MHz) and Bruker AM-400 spectrometer $(400 \mathrm{MHz}),{ }^{13} \mathrm{C}$ NMR spectra were measured on a Bruker AM-400 (100 MHz) and Bruker Avance DRX 500 (125 MHz) spectrometers in DMSO- $d_{6}, \mathrm{CDCl}_{3}$ and trifluoroacetic acid (TFA) using TMS as internal standard. The mass spectra were recorded on a Varian 1200L GC-MS instrument, ionization by $\mathrm{EI}$ at $70 \mathrm{eV}$. Fast atom bombardment (FAB) mass spectrometry was performed on a VG 70-70EQ mass spectrometer, equipped with an argon primary atom beam, and a $m$-nitrobenzyl alcohol matrix was used. LC-MS experiments were performed on an Applied Biosystems (Shimadzu 10-AV LC, Gilson-215 automatic giving, mass spectrometer API 150EX, detectors UV (215 and $254 \mathrm{~nm}$ ), and ELS, column Luna-C18, Phenomenex, $5 \mu$, 100 Angstrom, $150 \times 2 \mathrm{~mm} \mathrm{RP}$ ). Elemental analyses were made on an elemental analyzer Euro AE-3000. The progress of reactions and the purity of the obtained compounds were monitored by TLC on Silufol UV-254 plates in EtOAc/ $\mathrm{CH}_{2} \mathrm{Cl}_{2}$ (1:4) and visualized under UV light or iodine fume. 
General procedure for the synthesis of 5-((2-amino-4-aryl$1 H$-imidazol-5-yl)(aryl)methyl)-6-hydroxy-2,2-dimethyl-4H1,3-dioxin-4-ones: An equimolar mixture $(1.0 \mathrm{mmol})$ of the corresponding 2-amino-4-arylimidazole $\mathbf{1}$, aromatic aldehyde 2 and Meldrum's acid 3 was refluxed in iPrOH $(3 \mathrm{~mL})$ for 3-5 min. After cooling, the solid products 4 were filtered off, washed with iPrOH and dried on air. 4a: colourless solid, 77\%; mp 243-245 ${ }^{\circ} \mathrm{C}$; IR $\left(\mathrm{KBr}, \mathrm{cm}^{-1}\right)$ v: 3404-2800 $\left(\mathrm{NH}_{2}, \mathrm{NH}, \mathrm{OH}\right)$, $1684(\mathrm{C}=\mathrm{O}) ;{ }^{1} \mathrm{H}$ NMR (200 MHz, DMSO- $\left.d_{6}\right) \delta 12.27$ (br s, $2 \mathrm{H}$, $\mathrm{NH}, \mathrm{OH}), 7.61-7.49$ (m, 2H, $\left.\mathrm{H}_{\text {arom }}\right), 7.48-7.31$ (m, 5H, $\mathrm{H}_{\text {arom }}$ ), 7.27-7.01 (m, 5H, NH $\left.2, \mathrm{H}_{\text {arom}}\right), 5.48(\mathrm{~s}, 1 \mathrm{H}, \mathrm{CH}), 1.51(\mathrm{~s}, 6 \mathrm{H}$, $\left.\mathrm{CH}_{3}\right) ;{ }^{13} \mathrm{C}$ NMR $\left(125 \mathrm{MHz}, \mathrm{CDCl}_{3}\right) \delta 166.8(\mathrm{C}=\mathrm{O}), 146.6$ (C-OH), 144.0, 129.4, 128.9, 128.4, 128.3, 127.5, 127.4, 127.2, 125.9, 121.1, 100.6, $76.0(\mathrm{C}=\mathrm{COH}), 35.1(\mathrm{CH}), 26.4\left(\mathrm{CH}_{3}\right)$, $25.9\left(\mathrm{CH}_{3}\right)$; $\mathrm{MS}(\mathrm{m} / \mathrm{z})(\%): 289(76),\left(391\left[\mathrm{M}^{+\bullet}\right]-44-58\right), 247$ (53), 159 (36), 104 (19), 77 (8), 44 (39), 43 (100); anal. calcd for $\mathrm{C}_{22} \mathrm{H}_{21} \mathrm{~N}_{3} \mathrm{O}_{4}(391.5) \mathrm{C}, 67.52 ; \mathrm{H}, 5.37 ; \mathrm{N}, 10.74$; found: $\mathrm{C}$, $68.77 ; \mathrm{H}, 5.93 ; \mathrm{N}, 10.79$.

General procedure for the synthesis of 5-oxo-1,7-diaryl-6,7dihydro-5 $H$-pyrrolo[1,2-c]imidazol-3-aminium 2,2,2-trifluoroacetates: A mixture of the corresponding adduct 4 $(0.1 \mathrm{mmol})$ and $0.08 \mathrm{~mL}(0.11 \mathrm{mmol}) \mathrm{TFA}$ was refluxed in $1 \mathrm{~mL}$ of toluene for $3 \mathrm{~min}$. After cooling, $3 \mathrm{~mL}$ of $\mathrm{iPrOH}$ was added to the reaction mixture and the solid product 9 was filtered off, washed with iPrOH and dried on air. 9b: colourless solid, 52\%; mp 222-224 ${ }^{\circ} \mathrm{C}$; IR $\left(\mathrm{KBr}, \mathrm{cm}^{-1}\right)$ v: 3432-3160 $\left(\mathrm{NH}_{3}{ }^{+}, \mathrm{COO}^{-}\right), 1782(\mathrm{C}=\mathrm{O}) ;{ }^{1} \mathrm{H}$ NMR $\left(400 \mathrm{MHz}, \mathrm{DMSO}-d_{6}\right) \delta$ 8.54 (br s, $\left.2 \mathrm{H}, \mathrm{NH}_{3}{ }^{+}\right), 7.29-7.16\left(\mathrm{~m}, 6 \mathrm{H}, \mathrm{H}_{\text {arom }}\right), 7.15-7.03(\mathrm{~m}$, $\left.3 \mathrm{H}, \mathrm{H}_{\text {arom }}\right), 4.81\left(\mathrm{~d}, J=3.6 \mathrm{~Hz}, 1 \mathrm{H}, \mathrm{CH}_{\mathrm{X}}\right), 3.81\left(\mathrm{dd}, J_{\mathrm{BX}}=\right.$ $\left.9.3 \mathrm{~Hz}, J_{\mathrm{AB}}=18.6 \mathrm{~Hz}, 1 \mathrm{H}, \mathrm{CH}_{\mathrm{B}}\right), 2.91\left(\mathrm{~d}, J_{\mathrm{AX}}=3.8 \mathrm{~Hz}, J_{\mathrm{AB}}=\right.$ $\left.18.7 \mathrm{~Hz}, 1 \mathrm{H}, \mathrm{CH}_{\mathrm{A}}\right), 2.20\left(\mathrm{~s}, 3 \mathrm{H}, \mathrm{CH}_{3}\right) ;{ }^{13} \mathrm{C} \mathrm{NMR}(100 \mathrm{MHz}$, DMSO- $\left.d_{6}\right) \delta 170.2(\mathrm{C}=\mathrm{O}), 143.4,137.7,137.1,129.9,129.4$, 129.2, 128.7, 128.4, 127.9, 125.8, 125.5, 46.2, 36.9, $21.1\left(\mathrm{CH}_{3}\right)$; LC-MS: $304\left(\mathrm{M}-\mathrm{CF}_{3} \mathrm{COO}^{-}\right), 305\left(\mathrm{M}-\mathrm{CF}_{3} \mathrm{COO}^{-}+\mathrm{H}\right)$.

General procedure for the synthesis of 3-amino-1,7diphenyl-6,7-dihydro-5H-pyrrolo[1,2-c]imidazol-5-one (10a): A mixture of the adduct $4 \mathrm{a}(0.1 \mathrm{mmol})$ and $0.08 \mathrm{~mL}$ $(0.11 \mathrm{mmol})$ of TFA was stirred in $2 \mathrm{~mL}$ of acetonitrile for $6 \mathrm{~h}$, then conc. aqueous solution of $\mathrm{NH}_{3}$ was added to $\mathrm{pH} \approx 8$ and the solid product was filtered off, dried on air and crystallized from $\mathrm{iPrOH}$. The title compound was obtained as a colourless solid $(0.20 \mathrm{~g}, 68 \%)$; mp $198-200{ }^{\circ} \mathrm{C}$; IR $\left(\mathrm{KBr}, \mathrm{cm}^{-1}\right) \mathrm{v}$ : 3486-3100 $\left(\mathrm{NH}_{2}\right), 1784(\mathrm{C}=\mathrm{O})$; ${ }^{1} \mathrm{H}$ NMR $(200 \mathrm{MHz}$, DMSO$\left.d_{6}\right) \delta 7.43-6.99\left(\mathrm{~m}, 10 \mathrm{H}, \mathrm{H}_{\text {arom }}\right), 6.36$ (br s, $\left.2 \mathrm{H}, \mathrm{NH}_{2}\right), 4.75$ (d, $\left.J=2.9 \mathrm{~Hz}, 1 \mathrm{H}, \mathrm{CH}_{\mathrm{X}}\right), 3.83,\left(\mathrm{dd}, J_{\mathrm{BX}}=9.2 \mathrm{~Hz}, J_{\mathrm{AB}}=17.9 \mathrm{~Hz}\right.$, $\left.1 \mathrm{H}, \mathrm{CH}_{\mathrm{B}}\right), 2.87\left(\mathrm{~d}, J_{\mathrm{AX}}=3.3 \mathrm{~Hz}, J_{\mathrm{AB}}=18.6 \mathrm{~Hz}, 1 \mathrm{H}, \mathrm{CH}_{\mathrm{A}}\right)$; ${ }^{13} \mathrm{C}$ NMR (125 MHz, DMSO- $\left.d_{6}\right) \delta 169.6(\mathrm{C}=\mathrm{O}), 143.9,142.5$, 133.8, 129.7, 129.4, 128.5, 127.8, 127.6, 127.5, 126.5, 125.4, 47.6, 36.9; MS (m/z) (\%): $289(76)\left[\mathrm{M}^{+\bullet}\right], 247$ (53), 159 (38),
104 (29), 77 (100), 44 (41), 43 (19); anal. calcd for $\mathrm{C}_{18} \mathrm{H}_{15} \mathrm{~N}_{3} \mathrm{O}$ (289.12) C, 74.74; H, 5.19; N, 14.53; found: C, 72.28; H, 6.79; $\mathrm{N}, 13.11$.

General procedure for the synthesis of 3-(2-amino-4-aryl$1 \mathrm{H}$-imidazol-5-yl)-3-arylpropanoic acids: A mixture of the corresponding adduct $4(0.1 \mathrm{mmol})$ and $0.08 \mathrm{~mL}(0.11 \mathrm{mmol})$ of TFA was stirred in $2 \mathrm{~mL}$ of aqueous acetonitrile for 10-12 h. After cooling, the solid products $\mathbf{1 1}$ were filtered off, washed with $\mathrm{iPrOH}$ and dried on air. 11b: pale yellow solid, 55\%; mp 282-285 ${ }^{\circ} \mathrm{C} ;{ }^{1} \mathrm{H}$ NMR (200 MHz, DMSO- $\left.d_{6}\right) \delta 7.38-7.23$ (m, 4H, $\mathrm{H}_{\text {arom }}$ ), 7.22-6.98 (m, 5H, $\mathrm{H}_{\text {arom }}$ ), 5.72 (br s, 2H, $\mathrm{NH}_{2}$ ), 4.50-4.37 (m, 1H, $\left.\mathrm{CH}_{\mathrm{X}}\right), 3.04-2.71\left(\mathrm{~m}, 2 \mathrm{H}, \mathrm{H}_{\mathrm{A}} \mathrm{H}_{\mathrm{B}}\right), 2.21(\mathrm{~s}$, $\left.3 \mathrm{H}, \mathrm{CH}_{3}\right) ;{ }^{13} \mathrm{C} \mathrm{NMR}\left(125 \mathrm{MHz}, \mathrm{DMSO}-d_{6}\right) \delta 172.8(\mathrm{COOH})$, $147.9,136.6,135.5,134.5,129.8,129.4,128.8,128.1,127.9$, $127.8,127.4,36.7,33.4,21.0\left(\mathrm{CH}_{3}\right)$; $\mathrm{MS}(\mathrm{m} / \mathrm{z})(\%): 321(25)$ $\left[\mathrm{M}^{+\bullet}\right], 303$ (25), 262 (100), 247 (15), 204 (10), 172 (11), 142 (20), 115 (22), 84 (22); anal. calcd for $\mathrm{C}_{19} \mathrm{H}_{19} \mathrm{~N}_{3} \mathrm{O}_{2}$ (321.15) $\mathrm{C}$, 71.01; H, 5.96; N, 13.08; found: C, 70.98; H, 6.06; N, 13.85 .

General procedure for the synthesis of 5-amino-3-(arylideneamino)-1,7-diaryl-7H-pyrrolo[1,2-c]imidazole-6-carbonitriles: A mixture of the corresponding 2-amino-4-arylimidazole $1(1.0 \mathrm{mmol})$, aromatic aldehyde $2(2.0 \mathrm{mmol})$ and malononitrile $12(1.0 \mathrm{mmol})$ in $2 \mathrm{~mL}$ of 2-propanol was refluxed during 20-30 min. After cooling, the yellow solid products 14 were filtered off and crystallized from iPrOH. 14a: yellow powder, 65\%; mp 221-222 ${ }^{\circ} \mathrm{C}$; ${ }^{1} \mathrm{H} \mathrm{NMR}(200 \mathrm{MHz}$, DMSO- $\left.d_{6}\right) \delta 9.34\left(\mathrm{~s}, 1 \mathrm{H}, \mathrm{CH}_{\text {azomethine }}\right), 8.18(\mathrm{~d}, J=7.3 \mathrm{~Hz}$, 2H, Ar), 7.68-7.48 (m, 7H, Ar, $\mathrm{C}^{5} \mathrm{NH}_{2}$ ), 7.31-7.10 (m, 8H, Ar), $5.34\left(\mathrm{~s}, 1 \mathrm{H}, \mathrm{C}^{7} \mathrm{H}\right) ;{ }^{13} \mathrm{C}$ NMR $\left(125 \mathrm{MHz}, \mathrm{DMSO}-d_{6}\right) \delta$ $162.4\left(\mathrm{C}^{3}\right), 149.5$ ( $\left.\mathrm{C}_{\text {azomethine }}\right), 143.8\left(\mathrm{C}^{5}\right), 138.3,135.3,133.3$, $133.0,132.5,132.1,130.4,129.5,129.4,128.8,128.2,128.1$, 127.4, 125.8, $117.9(\mathrm{CN}), 71.7\left(\mathrm{C}^{6}\right), 45.01\left(\mathrm{C}^{7}\right)$; MS $(\mathrm{m} / \mathrm{z})(\%)$ : $429\left(\left[\mathrm{M}^{+\bullet}\right], 25\right), 285$ (100), 194 (19), 104 (26), 77 (19), 43 (25); anal. calcd for $\mathrm{C}_{28} \mathrm{H}_{23} \mathrm{~N}_{5}$ (429.53) C, 78.30; H, 5.40; N, 16.31; found: C, 80.25; H, 5.70; N, 13.41.

General procedure for the synthesis of 5-amino-1,7-diaryl-3(arylideneamino)-7H-pyrrolo[1,2-c]imidazole-6-carboxylates. A mixture of the corresponding 2-amino-4-arylimidazole $\mathbf{1}$ (1.0 mmol), aromatic aldehyde $2(2.0 \mathrm{mmol})$ and ethyl 2-cyanoacetate $15(1.0 \mathrm{mmol})$ in $2 \mathrm{~mL}$ of 2-propanol was refluxed during 20-30 min. After cooling, the yellow solid products 16 were filtered off and crystallized from iPrOH. 16a: yellow powder, 30\%, mp 239-240 ${ }^{\circ} \mathrm{C}$; ${ }^{1} \mathrm{H}$ NMR (200 MHz, DMSO- $d_{6}$ ) $\delta 9.32\left(\mathrm{~s}, 1 \mathrm{H}, \mathrm{CH}_{\text {azomethine }}\right), 8.12(\mathrm{~d}, J=6.7 \mathrm{~Hz}, 2 \mathrm{H}, \mathrm{Ar})$, 7.67-7.45 (m, 5H, Ar), 7.27-7.04 (m, 10H, $\left.\mathrm{C}^{5} \mathrm{NH}_{2}, \mathrm{Ar}\right), 5.15$ $\left(\mathrm{s}, J=6.7 \mathrm{~Hz}, 1 \mathrm{H}, \mathrm{C}^{7} \mathrm{H}\right), 4.05-3.84\left(\mathrm{~m}, 2 \mathrm{H}, \mathrm{OCH}_{2} \mathrm{CH}_{3}\right), 1.01$ (s, $\left.J=7.0,3 \mathrm{H}, \mathrm{OCH}_{2} \mathrm{CH}_{3}\right) ;{ }^{13} \mathrm{C} \mathrm{NMR}\left(125 \mathrm{MHz}, \mathrm{DMSO}-d_{6}\right) \delta$ 178.7 (CO), 134.5, 133.3, 130.2, 129.6, 128.7, 128.6, 128.3, 
127.8, 127.2, 127.0, 126.4, 125.8, 125.5, 116.7, 93.4, 58.9, 43.4, 14.7; $\mathrm{MS}(\mathrm{m} / \mathrm{z})(\%): 448\left(\left[\mathrm{M}^{+\bullet}\right], 100 ;\right.$ anal. calcd. for $\mathrm{C}_{28} \mathrm{H}_{24} \mathrm{~N}_{4} \mathrm{O}_{2}$ (448.19) $\mathrm{C}, 74.98 ; \mathrm{H}, 5.39 ; \mathrm{N}, 12.49$; found: $\mathrm{C}$, $75.12 ; \mathrm{H}, 4.89 ; \mathrm{N}, 11.37$.

General procedure for the synthesis of $3^{\prime}, 5^{\prime}$-diamino-1alkyl-2-oxo-1'-arylspiro[indolin-3,7'-pyrrolo[1,2-c]imidazole]-6'-carbonitriles: The mixture of corresponding 2-amino4-arylimidazoles $1(1.0 \mathrm{mmol})$, isatin $18(1.0 \mathrm{mmol})$ and malononitrile $12(1.0 \mathrm{mmol})$ in $2 \mathrm{~mL}$ of 2-propanol was refluxed during 50-60 min. After cooling, the solid products 19 were filtered off and crystallized from iPrOH. 19a: colourless solid, 60\%, mp 250-252 ${ }^{\circ} \mathrm{C},{ }^{1} \mathrm{H}$ NMR (200 MHz, DMSO- $\left.d_{6}\right) \delta$ 7.77 (br s, 2H, $\left.\mathrm{C}^{5} \mathrm{NH}_{2}\right), 7.37$ (t, $J=7.9 \mathrm{~Hz}, 1 \mathrm{H}, \mathrm{Ar}_{\text {isatin }}$ ), 7.24-7.10 (m, 2H, Ar), 7.10-6.95 (m, 4H, Ar), 6.94-6.82 (m, 2H, Ar), 6.47 (br s, 2H, $\mathrm{C}^{3} \mathrm{NH}_{2 \text { imidazole }}$ ), 3.21 (s, 3H, N ${ }^{l} \mathrm{CH}_{3}$ ); ${ }^{13} \mathrm{C}$ NMR (125 MHz, DMSO- $\left.d_{6}\right) \delta 176.3\left(\mathrm{C}^{2}\right), 154.2\left(\mathrm{C}^{5}\right)$, $146.4\left(\mathrm{C}^{3}\right), 145.7,135.4,133.0,132.2,130.7,130.3,129.0$, 127.2, 126.6, 126.1, 126.0, 111.7, $69.8\left(\mathrm{C}^{6}\right), 55.8\left(\mathrm{C}_{\text {spiro }}\right), 29.2$ $\left(\mathrm{N}^{l} \mathrm{CH}_{3}\right)$; MS $(\mathrm{m} / z)(\%): 369[\mathrm{M}+\mathrm{H}]^{+}(100)$; anal. calcd for $\mathrm{C}_{21} \mathrm{H}_{16} \mathrm{~N}_{6} \mathrm{O}$ (368.14) C, 68.47; H, 4.38; N, 22.81; found: $\mathrm{C}$, 69.43; H, 5.07; N, 22.64.

General procedure for the synthesis of $3^{\prime}, 5^{\prime}$-diamino-1alkyl-2-oxo-1'-arylspiro[indoline-3,7'-pyrrolo[1,2-c]imidazole]-6'-carboxylates: The mixture of corresponding 2-amino4-arylimidazoles $1(1.0 \mathrm{mmol})$, isatin $18(1.0 \mathrm{mmol})$ and ethyl 2-cyanoacetate $15(1.0 \mathrm{mmol})$ in $2 \mathrm{~mL}$ of 2-propanol was refluxed during 50-60 min. After cooling, the solid products 20 were filtered off and crystallized from iPrOH. 20a: colourless solid, 72\%, mp 280-282 ${ }^{\circ} \mathrm{C}$; ${ }^{1} \mathrm{H}$ NMR (200 MHz, DMSO- $\left.d_{6}\right) \delta$ 7.63 (br s, 2H, C ${ }^{5} \mathrm{NH}_{2}$ ), 7.29 (t, $J=7.5 \mathrm{~Hz}, 1 \mathrm{H}, \mathrm{Ar}$ ), 7.11-6.88 (m, 8H, Ar), 6.46 (br s, 2H, C $\left.{ }^{3} \mathrm{NH}_{2}\right), 3.83-3.63(\mathrm{~m}, 2 \mathrm{H}$, $\left.\mathrm{COCH}_{2} \mathrm{CH}_{3}\right), 3.21\left(\mathrm{~s}, 3 \mathrm{H}, \mathrm{N}^{1} \mathrm{CH} 3\right), 0.88-0.69(\mathrm{~m}, 3 \mathrm{H}$, $\left.\mathrm{COCH}_{2} \mathrm{CH}_{3}\right) ;{ }^{13} \mathrm{C} \mathrm{NMR}\left(125 \mathrm{MHz}, \mathrm{DMSO}-d_{6}\right) \delta 175.0\left(\mathrm{C}^{2}\right)$, $145.0\left(\mathrm{C}^{5}\right), 143.7\left(\mathrm{C}^{3}\right), 133.6,130.4,130.2,129.0,128.5$, $126.7,125.3,125.0,123.5,123.1,108.6,58.5\left(\mathrm{C}^{6}\right), 52.7$ $\left(\mathrm{C}_{\text {spiro }}\right), 33.4\left(\mathrm{COCH}_{2} \mathrm{CH}_{3}\right), 26.9\left(\mathrm{~N}^{1} \mathrm{CH}_{3}\right), 14.3\left(\mathrm{COCH}_{2} \mathrm{CH}_{3}\right)$; MS $(m / z)(\%): 416[\mathrm{M}+\mathrm{H}]^{+}(100)$; anal. calcd for $\mathrm{C}_{23} \mathrm{H}_{21} \mathrm{~N}_{5} \mathrm{O}_{3}$ (415.16) C, 66.49; H, 5.09; N, 16.86; found: C, 67.89; H, 5.64; $\mathrm{N}, 11.70$.

\section{Experimental part of $\mathrm{X}$-ray diffraction study}

The crystals of $9 \mathbf{i}\left(\mathrm{C}_{24} \mathrm{H}_{20} \mathrm{~N}_{3} \mathrm{O}^{+}, \mathrm{C}_{2} \mathrm{~F}_{3} \mathrm{O}_{2}{ }^{-}\right)$are triclinic. At $293 \mathrm{~K} a=8.4770(6), b=11.317(1), c=13.027(1) \AA, \alpha=$ $69.101(9)^{\circ}, \mathrm{b}=77.989(8)^{\circ}, \gamma=87.527(7)^{\circ}, V=1141.3(2) \AA^{3}$, $M_{\mathrm{r}}=479.45, Z=2$, space group $P \overline{1}, d_{\text {calc }}=1.395 \mathrm{~g} / \mathrm{cm}^{3}$, $\mu(\mathrm{Mo} \mathrm{Ka})=0.109 \mathrm{~mm}^{-1}, \mathrm{~F}(000)=496$. Intensities of 8769 reflections (3910 independent, $\left.R_{\text {int }}=0.027\right)$ were measured on the «Xcalibur-3» diffractometer (graphite monochromated Mo $\mathrm{K} \alpha$ radiation, $\mathrm{CCD}$ detector, $\omega$-scaning, $2 \Theta_{\max }=50^{\circ}$ ).
The crystals of $\mathbf{1 1 b}\left(\mathrm{C}_{19} \mathrm{H}_{19} \mathrm{~N}_{3} \mathrm{O}_{2} \cdot \mathrm{H}_{2} \mathrm{O}\right)$ are monoclinic. At $293 \mathrm{~K} a=16.4288(9), b=9.3556(4), c=12.1174(8) \AA, \beta=$ $110.151(7)^{\circ}, V=1748.5(2) \AA^{3}, M_{\mathrm{r}}=339.39, Z=4$, space group $P 21 / c, d_{\text {calc }}=1.289 \mathrm{~g} / \mathrm{cm}^{3}, \mu(\mathrm{Mo} \mathrm{Ka})=0.089 \mathrm{~mm}^{-1}, \mathrm{~F}(000)=$ 720. Intensities of 16955 reflections (5089 independent, $R_{\text {int }}=$ $0.060)$ were measured on the «Xcalibur-3» diffractometer (graphite monochromated Mo K $\alpha$ radiation, $\mathrm{CCD}$ detector, $\omega$-scaning, $2 \Theta_{\max }=60^{\circ}$ ).

The crystals of 16a $\left(\mathrm{C}_{28} \mathrm{H}_{24} \mathrm{~N}_{4} \mathrm{O}_{2}\right)$ are triclinic. At $293 \mathrm{~K} a=$ 8.322(3) $\AA, b=9.563(6) \AA, c=16.053(5) \AA, \alpha=94.08(4)^{\circ}, \beta=$ $101.46(3)^{\circ}, \gamma=109.97(4)^{\circ}, V=1163.3(10) \AA^{3}, M_{\mathrm{r}}=448.53$, $Z=2$, space group $P \overline{1}, d_{\text {calc }}=1.2804 \mathrm{~g} / \mathrm{cm}^{3}, \mu(\mathrm{Mo} \mathrm{Ka})=$ $0.083 \mathrm{~mm}^{-1}, \mathrm{~F}(000)=472$. Intensities of 12048 reflections (3968 independent, $R_{\text {int }}=0.167$ ) were measured on the «Xcalibur-3» diffractometer (graphite monochromated Mo K $\alpha$ radiation, $\mathrm{CCD}$ detector, $\omega$-scaning, $2 \Theta_{\max }=50^{\circ}$ ).

The crystals of $19 \mathrm{a}\left(\mathrm{C}_{24} \mathrm{H}_{25} \mathrm{~N}_{7} \mathrm{O}_{3}\right)$ are triclinic. At $293 \mathrm{~K} a=$ 7.9380(5) $\AA, b=8.4953(5) \AA, c=17.6908(9) \AA, \alpha=$ $98.891(4)^{\circ}, \beta=101.017(5)^{\circ}, \gamma=91.630(5)^{\circ}, V=1154.86(12)$ $\AA^{3}, M_{\mathrm{r}}=459.51, Z=2$, space group $P \overline{1}, d_{\text {calc }}=1.321 \mathrm{~g} / \mathrm{cm}^{3}$, $\mu($ Mo Ka $)=0.091 \mathrm{~mm}^{-1}, \mathrm{~F}(000)=484$. Intensities of 11884 reflections (6633 independent, $\left.R_{\text {int }}=0.0265\right)$ were measured on the «Xcalibur-3» diffractometer (graphite monochromated Mo $\mathrm{K} \alpha$ radiation, $\mathrm{CCD}$ detector, $\omega$-scaning, $2 \Theta_{\max }=50^{\circ}$ ).

The structures were solved by direct methods using the SHELXTL package [41]. The position of the hydrogen atoms were located from electron density difference maps and refined by the "riding" model with $\mathrm{U}_{\text {iso }}=n \mathrm{U}_{\text {eq }}$ of the carrier atom ( $n=1.5$ for methyl and hydroxy groups and for water molecules and $n=1.2$ for other hydrogen atoms) in the structures 11b and 16a. The hydrogen atoms of the compounds $11 \mathrm{~b}$ and 19a which take part in the formation of the hydrogen bonds were refined using the isotropic approximation as well as all hydrogen atoms in the structure 9i. Full-matrix least-squares refinement of the structures against F2 in anisotropic approximation for non-hydrogen atoms using 3879 (9i), 5051 (11b), 3968 (16a) and 6633 (19a) reflections was converged to: $\mathrm{w} R_{2}=$ $0.052\left(R_{1}=0.031\right.$ for 1903 reflections with $\left.\mathrm{F}>4 \sigma(\mathrm{F}), \mathrm{S}=0.964\right)$ for structure $9 \mathbf{i}, \mathrm{w} R_{2}=0.117\left(R_{1}=0.054\right.$ for 2480 reflections with $\mathrm{F}>4 \sigma(\mathrm{F}), \mathrm{S}=0.992)$ for structure $11 \mathrm{~b}, \mathrm{w} R_{2}=0.107\left(R_{1}=\right.$ 0.079 for 942 reflections with $\mathrm{F}>4 \sigma(\mathrm{F}), \mathrm{S}=0.881)$ for structure 16a and $\mathrm{w} R_{2}=0.147\left(R_{1}=0.065\right.$ for 3693 reflections with $\mathrm{F}>4 \sigma(\mathrm{F}), \mathrm{S}=1.045)$ for structure 19a. The final atomic coordinates, and crystallographic data for molecules $9 \mathbf{i}$ and $\mathbf{1 1 b}$ have been deposited to with the Cambridge Crystallographic Data Centre, 12 Union Road, CB2 1EZ, UK (fax: +44-1223-336033; e-mail: deposit@ccdc.cam.ac.uk) and are available on request quoting the deposition numbers CCDC 1855490 for 9i, CCDC 
1855491 for $\mathbf{1 1 b}$, CCDC 1895778 for $\mathbf{1 6 a}$ and CCDC 1895793 for 19a).

\section{Supporting Information}

\section{Supporting Information File 1}

Experimental and analytical data, X-ray diffraction studies and NMR spectra.

[https://www.beilstein-journals.org/bjoc/content/ supplementary/1860-5397-15-101-S1.pdf]

\section{Acknowledgements}

The authors thank the National Academy of Sciences of Ukraine for financial support in the frame of the projects "Creation of modern bases for obtaining and analyzing substances and components of materials for pharmaceutical purposes" (0119U100727) and "Investigation of structural features of nitrogen containing heterocycles with potential biological activity" (0119U100716).

\section{ORCID ${ }^{\circledR}$ iDs}

Irina S. Konovalova - https://orcid.org/0000-0001-6245-6642 Svetlana V. Shiskina - https://orcid.org/0000-0002-3946-1061

\section{References}

1. Lejeune, C.; Tian, H.; Appenzeller, J.; Ermolenko, L.; Martin, M.-T.; Al-Mourabit, A. J. Nat. Prod. 2013, 76, 903-908. doi:10.1021/np400048r

2. Edrada, R. A.; Stessman, C. C.; Crews, P. J. Nat. Prod. 2003, 66, 939-942. doi:10.1021/np020503d

3. Gautschi, J. T.; Whitman, S.; Holman, T. R.; Crews, P. J. Nat. Prod. 2004, 67, 1256-1261. doi:10.1021/np0340495

4. Tilvi, S.; Moriou, C.; Martin, M.-T.; Gallard, J.-F.; Sorres, J.; Patel, K.; Petek, S.; Debitus, C.; Ermolenko, L.; Al-Mourabit, A. J. Nat. Prod. 2010, 73, 720-723. doi:10.1021/np900539j

5. Wang, Y.-G.; Morinaka, B. I.; Reyes, J. C. P.; Wolff, J. J.; Romo, D.; Molinski, T. F. J. Nat. Prod. 2010, 73, 428-434. doi:10.1021/np900638e

6. Smith, S. E.; Dello Buono, M. C.; Carper, D. J.; Coleman, R. S.; Day, B. W. J. Nat. Prod. 2014, 77, 1572-1578. doi:10.1021/np4010882

7. Kobayashi, J.; Nakamura, H.; Ohizumi, Y. Experientia 1988, 44, 86-87. doi:10.1007/bf01960260

8. Chan, G. W.; Mong, S.; Hemling, M. E.; Freyer, A. J.; Offen, P. H.; DeBrosse, C. W.; Sarau, H. M.; Westley, J. W. J. Nat. Prod. 1993, 56, 116-121. doi:10.1021/np50091a016

9. Meijer, L.; Thunnissen, A.-M.; White, A.; Garnier, M.; Nikolic, M.; Tsai, L.-H.; Walter, J.; Cleverley, K.; Salinas, P.; Wu, Y.-Z.; Biernat, J.; Mandelkow, E.-M.; Kim, S.-H.; Pettit, G. R. Chem. Biol. 2000, 7, 51-63. doi:10.1016/s1074-5521(00)00063-6

10. Tasdemir, D.; Mallon, R.; Greenstein, M.; Feldberg, L. R.; Kim, S. C.; Collins, K.; Wojciechowicz, D.; Mangalindan, G. C.; Concepción, G. P.; Harper, M. K.; Ireland, C. M. J. Med. Chem. 2002, 45, 529-532. doi:10.1021/jm0102856
11. Dunbar, D. C.; Rimoldi, J. M.; Clark, A. M.; Kelly, M.; Hamann, M. T. Tetrahedron 2000, 56, 8795-8798. doi:10.1016/s0040-4020(00)00821-8

12. Fu, X.; Schmitz, F. J.; Tanner, R. S.; Kelly-Borges, M. J. Nat. Prod. 1998, 61, 384-386. doi:10.1021/np970453q

13. Cafieri, F.; Carnuccio, R.; Fattorusso, E.; Taglialatela-Scafati, O.; Vallefuoco, T. Bioorg. Med. Chem. Lett. 1997, 7, 2283-2288. doi:10.1016/s0960-894x(97)00415-0

14. Gibbons, J. B.; Gligorich, K. M.; Welm, B. E.; Looper, R. E. Org. Lett. 2012, 14, 4734-4737. doi:10.1021/ol3019242

15. Jacquot, D. E. N.; Lindel, T. Curr. Org. Chem. 2005, 9, 1551-1565. doi:10.2174/138527205774370531

16. Su, S.; Rodriguez, R. A.; Baran, P. S. J. Am. Chem. Soc. 2011, 133, 13922-13925. doi:10.1021/ja206191g

17. Ermolat'ev, D. S.; Babaev, E. V.; Van der Eycken, E. V. Org. Lett. 2006, 8, 5781-5784. doi:10.1021/ol062421c

18. Ermolat'ev, D. S.; Van der Eycken, E. V. J. Org. Chem. 2008, 73 6691-6697. doi:10.1021/jo8008758

19. Ermolat'ev, D. S.; Svidritsky, E. P.; Babaev, E. V.; Van der Eycken, E. Tetrahedron Lett. 2009, 50, 5218-5220. doi:10.1016/j.tetlet.2009.06.128

20. Ermolat'ev, D. S.; Alifanov, V. L.; Rybakov, V. B.; Babaev, E. V.; Van der Eycken, E. V. Synthesis 2008, 2083-2088. doi:10.1055/s-2008-1078444

21. Modha, S. G.; Mehta, V. P.; Ermolat'ev, D.; Balzarini, J.; Van Hecke, K.; Van Meervelt, L.; Van der Eycken, E. Mol. Diversity 2010, 14, 767-776. doi:10.1007/s11030-009-9221-1

22. Steenackers, H. P. L.; Ermolat'ev, D. S.; Savaliya, B.; De Weerdt, A.; De Coster, D.; Shah, A.; Van der Eycken, E. V.; De Vos, D. E.; Vanderleyden, J.; De Keersmaecker, S. C. J. J. Med. Chem. 2011, 54, 472-484. doi:10.1021/jm1011148

23. Steenackers, H. P. L.; Ermolat'ev, D. S.; Savaliya, B.; De Weerdt, A.; De Coster, D.; Shah, A.; Van der Eycken, E. V.; De Vos, D. E.; Vanderleyden, J.; De Keersmaecker, S. C. J. Bioorg. Med. Chem. 2011, 19, 3462-3473. doi:10.1016/j.bmc.2011.04.026

24. Andriushchenko, A. Yu.; Saraev, V. E.; Shishkina, S. V.; Shishkin, O. V.; Musatov, V. I.; Desenko, S. M.; Chebanov, V. A. ARKIVOC 2013, No. iii, 61-80. doi:10.3998/ark.5550190.0014.306

25. Lipson, V. V.; Gorobets, N. Y. Mol. Diversity 2009, 13, 399-419. doi:10.1007/s11030-009-9136-x

26. Oikawa, Y.; Hirasawa, H.; Yonemitsu, O. Tetrahedron Lett. 1978, 19 1759-1762. doi:10.1016/0040-4039(78)80037-9

27. Dardennes, E.; Kovács-Kulyassa, Á.; Renzetti, A.; Sapi, J.; Laronze, J.-Y. Tetrahedron Lett. 2003, 44, 221-223. doi:10.1016/s0040-4039(02)02537-6

28. Jeannin, L.; Boisbrun, M.; Nemes, C.; Cochard, F.; Laronze, M.; Dardennes, E.; Kovács-Kulyassa, Á.; Sapi, J.; Laronze, J.-Y. C. R. Chim. 2003, 6, 517-528. doi:10.1016/s1631-0748(03)00092-4

29. Cochard, F.; Laronze, M.; Sigaut, P.; Sapi, J.; Laronze, J.-Y. Tetrahedron Lett. 2004, 45, 1703-1707. doi:10.1016/j.tetlet.2003.12.099

30. Dardennes, E.; Kovács-Kulyassa, Á.; Boisbrun, M.; Petermann, C.; Laronze, J.-Y.; Sapi, J. Tetrahedron: Asymmetry 2005, 16, 1329-1339. doi:10.1016/j.tetasy.2005.02.008

31. Gerencsér, J.; Panka, G.; Nagy, T.; Egyed, O.; Dormán, G.; Ürge, L.; Darvas, F. J. Comb. Chem. 2005, 7, 530-538. doi:10.1021/cc040101j

32. Bürgi, H.-B.; Dunitz, J. D., Eds. Structure correlation; VCH: Weinheim, Germany, 1994; pp 741-784. doi:10.1002/9783527616091 
33. Tsuji, M.; Inoue, H.; Tanoue, Y.; Beppu, K.; Saita, M.; Taniguchi, Y.; Furuta, K.; Deguchi, Y.; Noda, K.

3-Aroyl-6,7-dihydro-5H-pyrrolo(1,2-c)imidazole-7-carboxylic acid derivatives. U.S. Pat. Appl. US4895956A, Jan 23, 1990.

34. Chatterjee, S.; Ye, G.; Pittman, C. U., Jr. Tetrahedron Lett. 2010, 51, 1139-1144. doi:10.1016/j.tetlet.2009.10.116

35. Meredith, E. L.; Ksander, G.; Monovich, L. G.; Papillon, J. P. N.; Liu, Q.; Miranda, K.; Morris, P.; Rao, C.; Burgis, R.; Capparelli, M.; Hu, Q.-Y.; Singh, A.; Rigel, D. F.; Jeng, A. Y.; Beil, M.; Fu, F.; Hu, C.-W.; LaSala, D. ACS Med. Chem. Lett. 2013, 4, 1203-1207. doi: $10.1021 / \mathrm{ml} 400324 \mathrm{c}$

36. Ksander, G. M.; Meredith, E. M.; Monovich, L. G.; Papillon, J.; Firooznia, F.; Hu, Q.-Y. Condensed imidazole derivatives for the inhibition of aldosterone synthase and aromatase. WO Patent WO2007024945, March 1, 2007.

37. Pavlovska, T. L.; Redkin, R. G.; Lipson, V. V.; Atamanuk, D. V. Mol. Diversity 2016, 20, 299-344. doi:10.1007/s11030-015-9629-8

38. da Silva, J. F. M.; Garden, S. J.; Pinto, A. C. J. Braz. Chem. Soc. 2001, 12, 273-324. doi:10.1590/s0103-50532001000300002

39. Zhou, F.; Liu, Y.-L.; Zhou, J. Adv. Synth. Catal. 2010, 352, 1381-1407. doi:10.1002/adsc.201000161

40. Mohammadi, S.; Heiran, R.; Herrera, R. P.; Marqués-López, E. ChemCatChem 2013, 5, 2131-2148. doi:10.1002/cctc.201300050

41. Sheldrick, G. M. Acta Crystallogr., Sect. A: Found. Crystallogr. 2008, 64, 112-122. doi:10.1107/s0108767307043930

\section{License and Terms}

This is an Open Access article under the terms of the Creative Commons Attribution License

(http://creativecommons.org/licenses/by/4.0). Please note that the reuse, redistribution and reproduction in particular requires that the authors and source are credited.

The license is subject to the Beilstein Journal of Organic Chemistry terms and conditions:

(https://www.beilstein-journals.org/bjoc)

The definitive version of this article is the electronic one which can be found at:

$\underline{\text { doi:10.3762/bjoc. } 15.101}$ 